\author{
UNIVERSIDADE DE SÃO PAULO \\ FACULDADE DE ZOOTECNIA E ENGENHARIA DE ALIMENTOS
}

GISELE FERNANDES DE OLIVEIRA

Influência da estocagem nas características sensoriais da margarina

Pirassununga/ SP

2019 
Influência da estocagem nas características sensoriais da margarina

\section{Versão Corrigida}

Dissertação de Mestrado apresentada à Faculdade de Zootecnia e Engenharia de Alimentos da Universidade de São Paulo, como parte dos requisitos para obtenção do título de Mestre em Ciências do Programa de Pós-Graduação em Gestão e Inovação na Indústria Animal.

Área de Concentração: Gestão e Inovação na Indústria Animal

Orientadora: Profa. Dra. Marta Mitsui Kushida 
Ficha catalográfica elaborada pelo

Serviço de Biblioteca e Informação, FZEA/USP,

com os dados fornecidos pelo(a) autor(a)

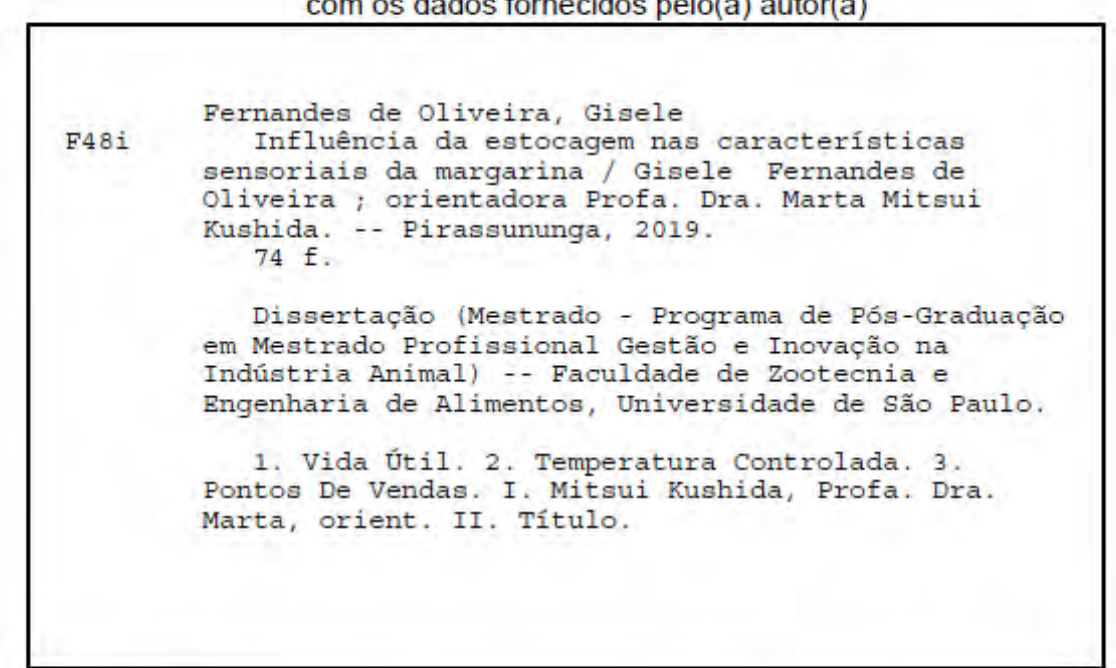

Permitida a cópia total ou parcial deste documento, desde que citada a fonte - o autor 


\title{
Influência da estocagem nas características sensoriais da margarina
}

\author{
Dissertação de Mestrado apresentado à Faculdade \\ de Zootecnia e Engenharia de Alimentos da \\ Universidade de São Paulo, como parte dos \\ requisitos para obtenção do título de Mestre em \\ Ciências do Programa de Pós-Graduação em \\ Gestão e Inovação na Indústria Animal. \\ Área de Concentração: Gestão e Inovação na \\ Indústria Animal
}

Data de aprovação:

Banca Examinadora:

Profa. Dra. Marta Kushida - Presidente da Banca Examinadora

Faculdade de Zootecnia e Engenharia de Alimentos (FZEA/USP) - Orientadora

Profa. Dra. Eliana Setsuko Kamimura

Faculdade de Zootecnia e Engenharia de Alimentos (FZEA/USP)

Profa. Dra. Judite, das Graças Lapa Guimarães

Faculdade de Zootecnia e Engenharia de Alimentos (FZEA/USP)

Prof. Dra. Selma Bergara

Sensel Consultoria e Treinamento em Análise Sensorial 
Dedico este trabalho ao meu esposo, pais, irmãos e familiar por todo amor e apoio incondicional em todos os momentos. 


\section{AGRADECIMENTOS}

Primeiramente agradeço à Deus pelo dom da vida, por iluminar meu caminho e me dar forças para seguir sempre em frente.

Aos meus pais Edna e José por terem me incentivado a estudar, pelos valores, por me ensinarem a viver com fé e a esperar o melhor da vida. Mãe, por tantas vezes ter renunciado seus sonhos para que eu pudesse realizar os meus.

Ao meu esposo Adriano pela paciência, apoio, compreensão, companheirismo, amizade.

Aos irmãos que Deus me presenteou Tatiane e Gabriel e aos que escolhi para amar como irmãos: Ana Paula, Diego. Ao meu afilhado Erik, a "Laysla" e aos meus queridos sobrinhos Henrique e Lívia. Á minha sogra Josefa sempre tão atenciosa e carinhosa. À todos meu amor incondicional, sempre. A distância não nos separa. Seus corações estão comigo e o meu com vocês

À minha família e aos verdadeiros amigos, em especial, às companheiras de trabalho e de estudo, Giovana F., Izabel P. e Tatiana N. que foram muito importantes nesta caminhada, me deram força! Foi muito bom poder contar com vocês!

À quem me apresentou a análise sensorial e as avaliações de margarina Maria Teresa G. e Patrícia M., imenso carinho, admiração e gratidão.

À minha orientadora Prof ${ }^{a}$ Dra Marta Mitsui Kushida por me auxiliar com todo o seu conhecimento, competência e sensibilidade. 
A persistência é o menor caminho para o êxito (Charles Chaplin) 


\section{RESUMO}

OLIVEIRA, G. F. Influência da estocagem nas características sensoriais da margarina. 2019. 76 f. Dissertação (Mestrado) - Faculdade de Zootecnia e Engenharia de Alimentos, Universidade de São Paulo, Pirassununga, 2019.

As margarinas têm grande representividade de consumo no mercado brasileiro, são facilmente encontradas em diversos tipos de estabelecimentos comerciais. Margarinas são emulsão água em óleo $(\mathrm{A} / \mathrm{O})$ que passam por diversas tranformações microbiológicas, físico-químicas que podem impactar nas caracteristicas sensoriais e na qualidade do produto final. Neste trabalho foram estudado características sensoriais das margarinas armazenadas em temperaturas controladas (nos periodos de 2, 45, 90, 135 e 180 dias) e condições reais de estocagem em diferentes pontos de venda. Em ambas estocagens foram avaliados atributos de cor amarela, gosto salgado, sabor amanteigado, sabor ranço, cremosidade e ponto de fusão. De forma quantitativa foi realizado uma comparação entre as médias dos atributos sensoriais, das condições reais e das condições controladas, todas as amostras com até 90 dias de estocagem, já que este tempo de vida útil representa mais que $80 \%$ das margarinas encontradas nos pontos comerciais. Foi comprovado quantitativamente que as amostras armazenadas em condições reais, estão mais susceptivéis as alterações e tendem a reduzir mais o derretimento na boca que o armazenamento em condições controlada e, por isso sugere-se que este fato também pode gerar reclamações dos consumidores.

Palavras-chave: Vida Útil; Temperatura Controlada; Pontos De Vendas. 


\section{ABSTRACT}

OLIVEIRA, G. F. Influence of storage on margarine sensory characteristics. 2019. 76 f. Dissertação (Mestrado) - Faculdade de Zootecnia e Engenharia de Alimentos, Universidade de São Paulo, Pirassununga, 2019.

The margarines have great representativity in the Brazilian market. They are often found in different types of commercial sources. Margarines are emulsifiers W/O that can pass through different microbiological, physical and chemical transformations that impact on the sensorial characteristics and the quality of the final product. Its quality is also influenced by storage temperature. In this study the performances of margarines stored in temperature chambers and in real conditions of storage temperature were studied. In both conditions, it was conducted the following sensory attributes: yellow color, salty flavor, butter flavor, rancid flavor, creaminess and melting point. A qualitative comparison was made between the average sensory attributes, real conditions and controlled conditions of the samples, both with up to 90 days of storage, as this shelf life represents more than $80 \%$ of margarines found at commercial points, it has been quantitatively proven that samples stored under real conditions are more susceptible to change and going to reduce melt in the mouth more than controlled storage, so it is suggested that this may also lead to consumer complaints.

Key words: Shelf life, temperature control, sales points 


\section{LISTA DE FIGURAS}

Figura 1: Penetração de Spreads (produtos espalháveis) no Brasil (\%) .......... 20

Figura 2: Frequência de compra de margarinas, quando relacionado com outros produtos espalháveis (Número de compra/Ano) ................... 21

Figura 3: Fluxograma do processo de produção de margarinas ...................... 22

Figura 4: Ficha sensorial utilizada durante o estudo sensorial ....................... 42

Figura 5: Número de reclamações de clientes recebidas pelo SAC da empresa "A" durante o ano de 2018

Figura 6: Gráfico de Pareto apresentando a classificação dos principais problemas relacionados aos aspectos sensoriais de margarinas produzidas pela empresa "A", das reclamações obtidas pelo SAC no ano de 2018 45

Figura 7: Gráfico de Pareto apresentando a classificação dos principais problemas relacionados ao sabor de margarinas produzidas pela empresa "A", das reclamações obtidas pelo SAC no ano de 2018. . 46

Figura 8: Tempo de vida útil das margarinas avaliadas sensorialmente 52

Figura 9: Comparativo das características sensoriais 56 


\section{LISTA DE TABELAS}

Tabela 1: Problemas processo de margarina ................................................ 30

Tabela 2: Frequência de avaliação das amostras de margarinas .................... 39

Tabela 3: Frequências relativas dos dados de reclamações obtidas pelo SAC no ano de 2018, relativas à características sensoriais de margarinas ............. 44

Tabela 4: Frequências relativas dos dados de reclamações obtidas pelo SAC no ano de 2018 , relativas à características de sabor de margarinas ............... 45

Tabela 5: Resultados da avaliação das margarinas estocadas em condições

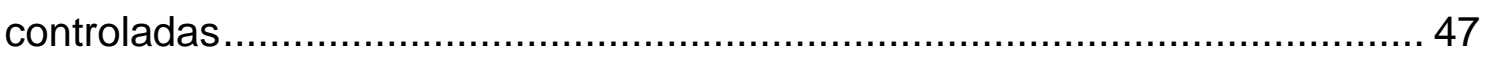

Tabela 6: Temperaturas das margarinas nos pontos de venda .......................51

Tabela 7: Média e a diferença mínima significativa (DMS) dos atributos sensoriais 53 


\section{LISTA DE QUADROS}

Quadro 1: Formas de relacionamento do consumidor com um problema apresentado pelo produto adquirido ........................................................ 18

Quadro 2: Classificação de tipos de comércios varejistas: .............................. 33

Quadro 3: Informações constantes no rótulo da embalagem da margarina

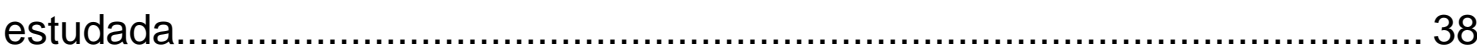




\section{LISTA DE SIGLAS}

$\begin{array}{ll}\alpha & \text { Alfa } \\ \beta & \text { Beta } \\ \beta & \text { Beta prima } \\ \text { ANOVA } & \text { Análise de variância } \\ \text { A/O } & \text { Emulsão de água em óleo } \\ \text { ASTM } & \text { American Society for Testing and Materials } \\ \text { CEPH } & \text { Comitê de Ética em Pesquisa com Humanos } \\ \text { DAGs } & \text { Diacilgliceróis } \\ \text { DMS } & \text { Diferença Mínima Significativa } \\ \text { ISO } & \text { The International Organization for Standardization } \\ \text { MAPA } & \text { Ministério da Agricultura, Pecuária e Abastecimento } \\ \text { M/M } & \text { massa/massa } \\ \text { SAC } & \text { Serviço de assistência ao consumidor } \\ \text { pH } & \text { Potencial Hidrogeniônico } \\ \text { TCLE } & \text { Termo de Consentimento Livre e Esclarecido }\end{array}$




\section{Sumário}

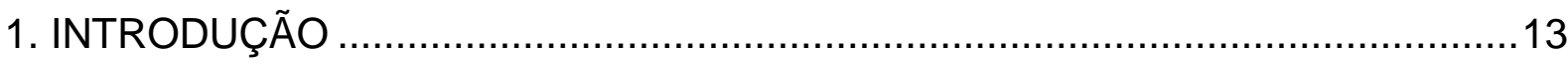

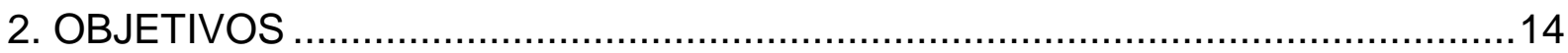

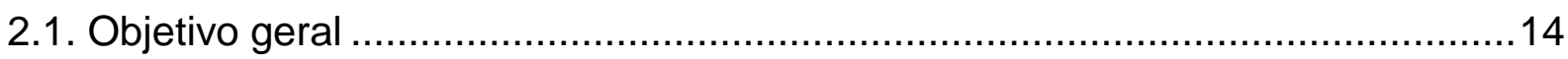

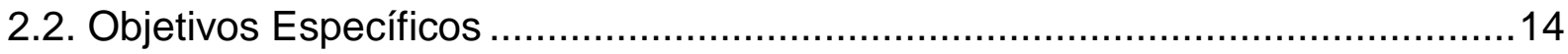

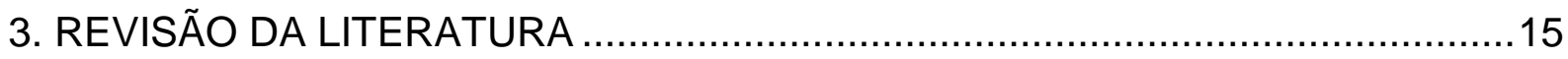

3.1. Gestão da qualidade na indústria de alimentos...........................................15

3.2 Serviço de assistência ao consumidor (SAC) ..............................................17

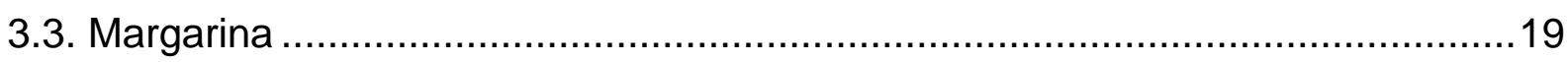

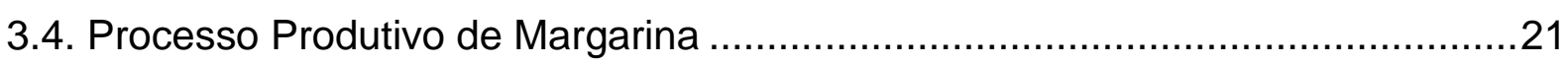

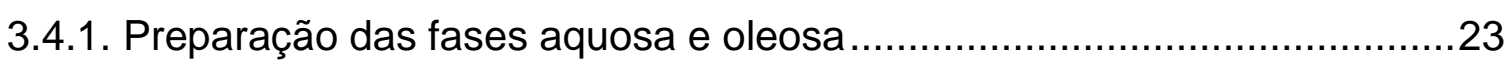

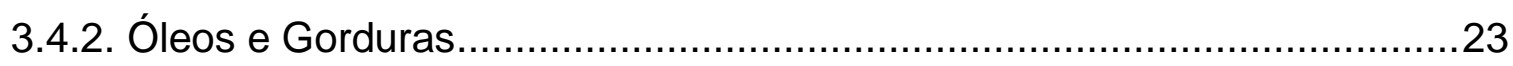

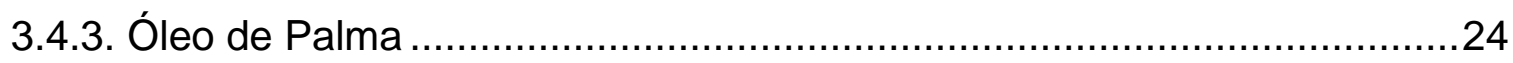

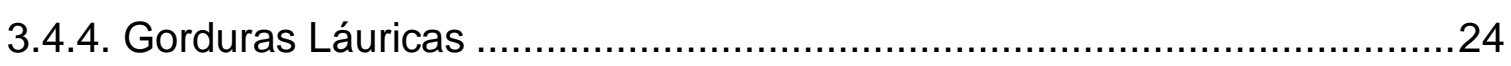

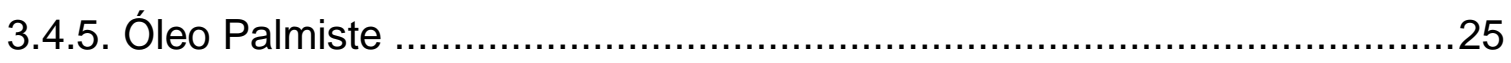

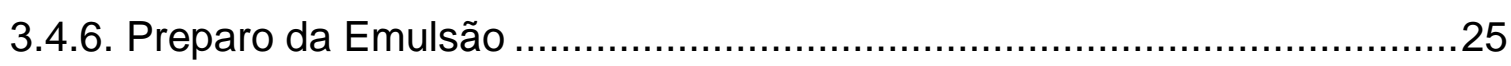

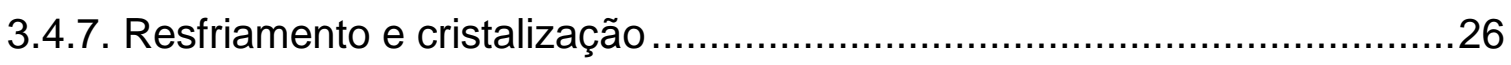

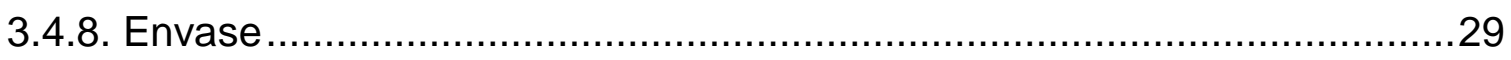

3.5. Importância do processo de produção na qualidade do produto final ................29

3.6. Principais alterações da margarina durante a estocagem.................................29

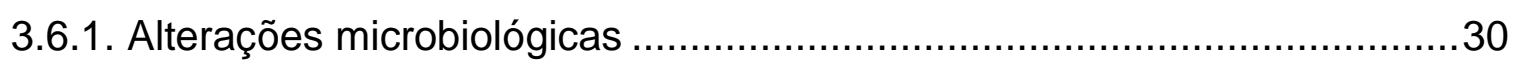

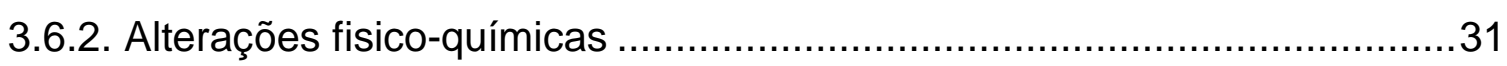

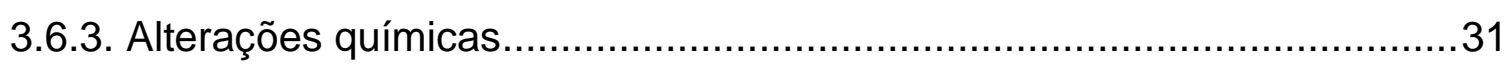

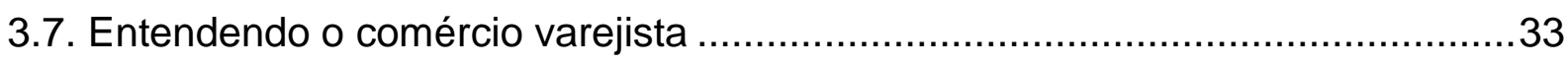

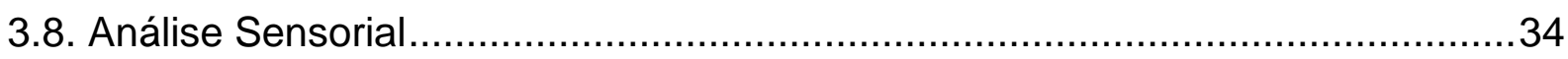

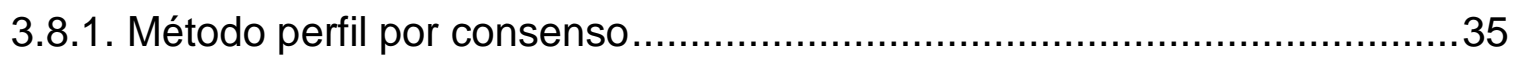

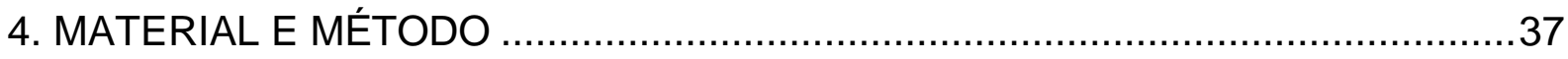

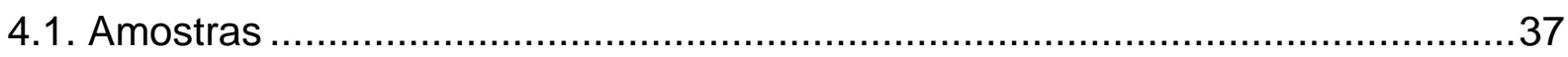

4.1.1. Obtenção das margarinas nos pontos de vendas ....................................37

4.1.2. Armazenamento das margarinas em condições controladas ....................39 


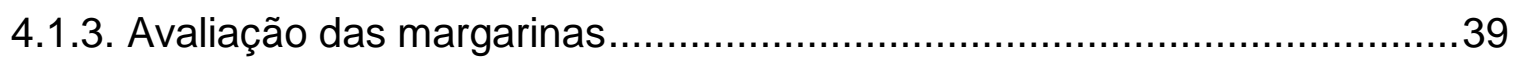

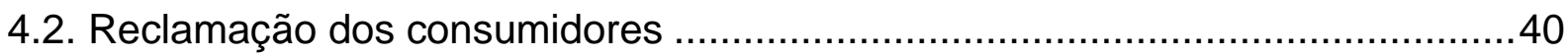

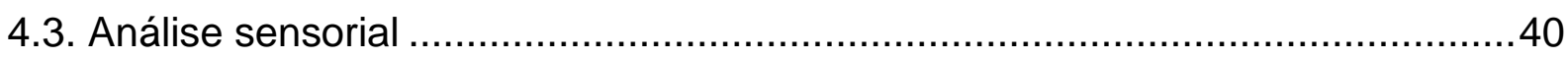

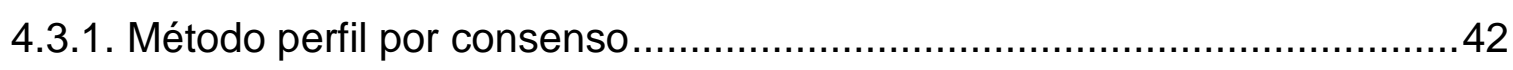

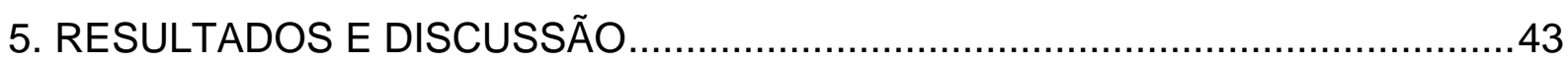

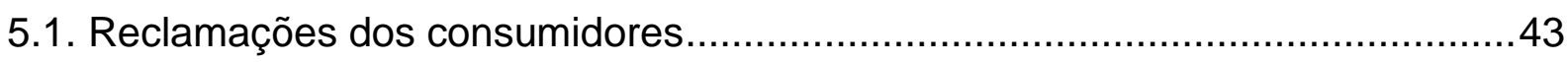

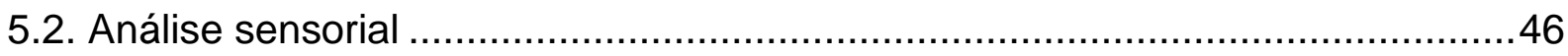

5.2.1. Características sensoriais das margarinas obtidas de condições

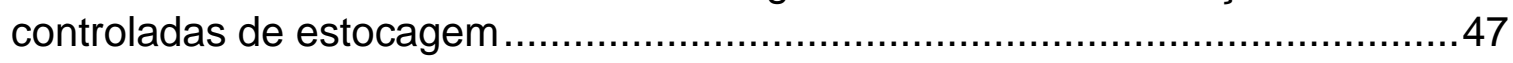

5.2.2. Características sensoriais da aparência das margarinas obtidas de condições controladas de estocagem......................................................4

5.2.3. Características sensoriais de sabor das margarinas obtidas de

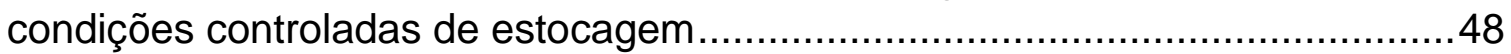

5.2.4. Características sensoriais de textura das margarinas obtidas de

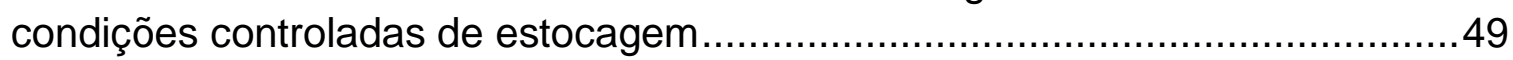

5.3. Avaliação da vida útil das margarinas nos pontos de vendas ...........................50

5.3.1. Temperatura das margarinas obtidas no ponto de venda........................50

5.3.2. Tempo de vida útil das margarinas dos pontos de venda .......................52

5.4. Características sensoriais das margarinas obtidas no ponto de venda...............52

5.4.1. Características sensoriais da aparência das margarinas obtidas nos

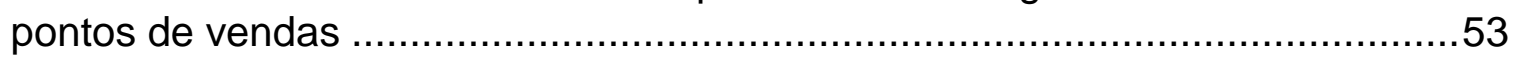

5.4.2. Características sensoriais de sabor e textura das margarinas obtidas

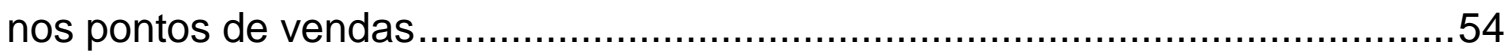

5.5. Comparativo das características sensoriais nas condições de estocagem .........55

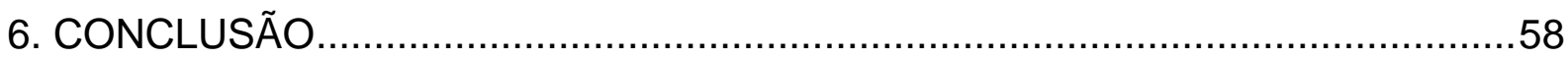

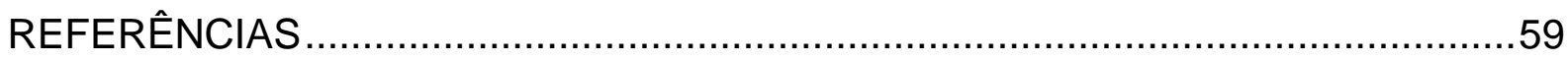

Apêndice A: Termo de Consentimento Livre e Esclarecido .....................................69

Apêndice B: Comprovante de aprovação do Comitê de Ética em Pesquisa com Humanos (CEPH) da Faculdade de Zootecnia e Engenharia de Alimentos (FZEA/USP) ....72 



\section{INTRODUÇÃO}

A margarina é uma emulsão de água em óleo $(\mathrm{A} / \mathrm{O})$ que surgiu na França em 1869. O produto foi desenvolvido pelo químico francês MégeMouries após uma solicitação do imperador por um produto que substituísse a manteiga (O'BRIEN, 2009). A invenção ganhou escala industrial e hoje ainda é um produto relevante nas mesas dos consumidores brasileiros devido ao baixo preço e boas características sensoriais.

De acordo com a portaria $\mathrm{n}^{\circ} 372$ de 04/09/1997 (BRASIL, 1997), margarina é definido como produto gorduroso em emulsão estável com leite ou seus constituintes ou derivados, e outros ingredientes, destinados à alimentação humana com cheiro e sabor característico, contendo até $95 \%$ de lipídios.

O processo produtivo da margarina contempla as etapas de preparo da fase aquosa e oleosa, emulsificação, resfriamento, cristalização e envase (PERIN, 2018). O processo de cristalização da gordura contempla a transformação dos cristais de gordura $(\alpha, \beta, \beta)$ que se iniciam durante 0 processo de produção da margarina e permanecem posteriomente durante 0 armazenamento, que conduzem a um aumento no tamanho dos cristais presentes (MCCLEMENTS, 2012). Os cristais produzidos na forma $\beta$ ' podem se transformar em $\beta$ sob certas condições de estocagem, dependendo da tendência do tipo da gordura utilizada em cristilizar na forma $\beta$. A forma $\beta$ é a mais estável do cristal de gordura e apresenta maior ponto de fusão. $O$ crescimento de cristais durante o armazenamento é muitas vezes indesejável, uma vez que afeta adversamente propriedades físico-químicas e sensoriais do produto final (CHRYSAM, 2005).

Uma margarina de alta qualidade deve derreter rapidamente em temperaturas corpóreas $\left(35-37^{\circ} \mathrm{C}\right)$. Durante esta fusão na boca ocorre primeiramente a liberação dos componentes da fase aquosa, que trazem a liberação de sabor e de sal e são imediatamente percebidos pelas papilas gustativas (CHRYSAN, 2005). O perfil de fusão da gordura, a estabilidade da emulsão e as condições de conservação do produto acabado, impactam em características sensoriais importantes como derretimento na boca, 
espalhabilidade e palatabilidade, que estão relacionados à qualidade do produto final (CHRYSAN, 2005, TORO-VAZQUEZ et al., 2000).

Considerando estas alterações dos cristais de gordura e seus possíveis impactos nas características sensoriais da margarina, o estudo propõe entender de maneira quantitativa se existe diferença nas intensidades dos atributos sensoriais de cor amarela, gosto salgado, sabor amanteigado, cremosidade, derretimento na boca que ocorrem durante a estocagem em condições controladas são iguais das condições reais de temperatura de estocagem, utilizando como ferramenta painel de avaliadores treinados, com experiência na avaliação deste tipo de produto, sendo portanto denominados experts. O resultado sensorial comparativo de ambas condições responderá de forma indicativa se podem ocorrer alterações sensoriais em maiores intensidades nas condições reais de temperatura, pontos de vendas, do que em condições controladas e se podem estar gerando reclamações dos consumidores.

\section{OBJETIVOS}

\subsection{Objetivo geral}

Realizar uma abordagem comparativa das alterações nas características sensoriais de margarinas entre condições controladas em laboratório e condições reais de estocagem em pontos de venda para compreender as reclamações geradas pelos consumidores.

\subsection{Objetivos Específicos}

1. Classificar as principais reclamações de consumidores referentes às características sensoriais (aparência, odor, sabor e textura) de margarina.

2. Avaliar alterações nas características sensoriais das margarinas estocadas em condições controladas.

3. Avaliar as alterações nas características sensoriais das margarinas coletadas nos pontos de vendas.

4. Entender se as alterações nas características são peculiares a ambas estocagens. 


\section{REVISÃO DA LITERATURA}

\subsection{Gestão da qualidade na indústria de alimentos}

No início século $X X$ as organizações já se preocupavam com a qualidade o que gerou evolução nos controles e melhoria contínua ao longo dos últimos anos (MENDES, 2007).

Para Correia (2005) e Andrade (2002) a qualidade pode ser traduzida como um conjunto de ações, ferramentas e sistemas que padronizam as atividades para oferecer produtos e serviços da forma como se espera. As exigências do mercado e de clientes fazem com que as organizações adotem sistemas que visam implementar a qualidade de forma efetiva. Avelino (2005) sintetizou as principais definições de qualidade nas organizações segundo alguns conceituados autores: Joseph M. Juran defende a importância de entender "o que o cliente quer". Philip Crosby relatava a qualidade focado no atendimento dos controles de processo (conformidade às especificações e produtos "zero de defeitos"). Kaoru Ishikawa traz a relevância de atender as exigências dos clientes. Genichi Taguchi enxerga a qualidade como a mínima perda causada ao consumidor.

O sistema da qualidade tem papel fundamental na indústria de alimentos e desde quando foi criado saiu de uma visão voltada apenas no processo produtivo para um foco mais amplo de qualidade voltado para várias áreas da cadeia industrial, trazendo para as empresas uma melhoria no monitoramento da qualidade e auxiliando no atendimento da expectativa do consumidor (CORREIA, 2005; ANDRADE, 2002).

De acordo com Ishikawa (1993) o controle de qualidade envolve desde os aspectos técnicos até a implementação de procedimentos e padrões, e ressalta a importância da gestão destes fatores de qualidade e do envolvimento de todos os níveis hierárquicos na empresa como indispensáveis na construção da satisfação do cliente no uso do produto ou serviço. Ele traz a importância de ouvir e entender o consumidor, pois até os problemas e os resultados não esperados servem como oportunidade de investigação da causa original, isto proporciona muito aprendizado e possibilita que o problema 
não volte a ocorrer. Toledo et al. (2013) e Avelino (2005), recomendam os principais pontos para uma efetiva gestão da qualidade:

- Comprometimento de todas as áreas da organização, inclusive da alta direção nos programas de melhoria de qualidade. Além de treinamentos de capacitação pessoal para todos os níveis da organização

- Definição e implementação de políticas e diretrizes do sistema da qualidade; assim como adoção de procedimentos padrões baseados na melhoria contínua;

- Busca constante aos propósitos da gestão da qualidade sem que haja desvios dos objetivos preestabelecidos.

Nesse contexto a gestão da qualidade deixa de ser um diferencial competitivo na indústria, para tornar-se uma exigência para se manter no mercado. Desta forma as empresas estão primeiramente voltadas para os aspectos qualidade $O$ que as torna mais competitivas e lucrativas em consequência desta forma de trabalho (BERTOLINO, 2010). A implementação da qualidade no produto, no processo, colocadas em prática nos estágios iniciais e intermediários de desenvolvimento de produtos, apontam melhorias voltadas para a satisfação do cliente de modo geral (TOLEDO et al. 2013). O fácil acesso as informações fazem com que os consumidores fiquem cada vez mais exigentes e seletivos nas suas escolhas (DATORRE; HERMOSILLA; SILVA, 2016).

Desta forma a gestão de qualidade não é um trabalho fácil, pois envolve diversas vertentes, entretanto o benefício de fidelizar seus clientes através do aumento da satisfação do cliente é o melhor resultado que as empresas podem ter, nesse contexto faz-se indispensável também uma investigação das reclamações recebidas através dos serviços de assistência aos consumidores (SAC) na busca por constantes melhorias e aprendizados. 


\subsection{Serviço de assistência ao consumidor (SAC)}

A Lei ํo 8.078 de 11 de setembro de 1990 do Código de Defesa do Consumidor, definiu novo enfoque de relação entre fornecedores e consumidores. Deste período em diante as empresas passaram a criar os chamados SAC - Serviço de Atendimento ao Consumidor, serviço de atendimento telefônico das prestadoras de serviço com intuito de resolver as demandas dos clientes que buscam informações, soluções de dúvidas, procuram fazer reclamações (BRASIL, 2008).

De acordo com Mendonça (2006) a relação entre a empresa e o consumidor por meio do SAC pode desenvolver-se de duas formas distintas:

- A empresa ouve as reclamações e sugestões e atende às necessidades e expectativas do consumidor, utilizando ainda as informações dos consumidores para melhoria de seus produtos e serviços de forma estratégica

- Nesta empresa as necessidades e expectativas do público são desconsideradas, existe um relacionamento basicamente comercial e resume-se apenas a coleta de informações e reclamações, sem processá-las e distribuí-las na organização.

De acordo com Kotler (2010) a satisfação do cliente é o sentimento de prazer resultante do efetivo atendimento das suas expectativas, e a insatisfação é o desapontamento do consumidor que não conseguiu atender sua expectativa gerada antes da compra. Em casos de desapontamento o consumidor deve ser ouvido, pois quando o consumidor reclama é sinal que tem interesse em continuar comprando o produto.

O relacionamento empresa e consumidor no momento do desapontamento pode ocorrer através do SAC, essa área tem o papel de ouvir o consumidor com paciência e atenção, pois isto também pode ser decisivo na recompra do produto e na fidelidade Kotler (2010).

O gerenciamento das reclamações envolve interações, procedimentos e mecanismos necessários para assegurar a lealdade dos 
consumidores, neste processo as reclamações são tratadas para que não gerem mais prejuízos ou insatisfação ao consumidor (SANTOS; ROSSI, 2002).

De acordo com alguns autores, existem diversas formas dos consumidores se relacionarem com os problemas apresentados, conforme apresentado no Quadro 1.

Quadro 1: Formas de relacionamento do consumidor com um problema apresentado pelo produto adquirido

\begin{tabular}{|l|c|l|}
\hline \multicolumn{1}{|c|}{ Autor } & Ano & $\begin{array}{l}\text { Relação consumidor x problema no } \\
\text { produto }\end{array}$ \\
\hline $\begin{array}{l}\text { Voorhees; Brady; } \\
\text { Horowitz }\end{array}$ & 2006 & $\begin{array}{l}\text { Consumidores que mesmo após uma } \\
\text { experiência negativa, escolhem não } \\
\text { reclamar e, ficam com a intenção de } \\
\text { recompra abaladas. }\end{array}$ \\
\hline $\begin{array}{l}\text { Bitner; Booms; } \\
\text { Tetreault }\end{array}$ & 1990 & $\begin{array}{l}\text { Consumidores que tendem a mudar } \\
\text { de marcas após uma experiência } \\
\text { negativa, o que reflete na perda da } \\
\text { confiança do consumidor. }\end{array}$ \\
\hline Mattila; Wirtz & 2004 & $\begin{array}{l}\text { Consumidores que demonstram sua } \\
\text { insatisfação reclamando nos serviços } \\
\text { de assistência ao consumidor da } \\
\text { empresa que forneceu o produto. }\end{array}$ \\
\hline Richins & 1983 & $\begin{array}{l}\text { consumidores insatisfeitos que } \\
\text { compartilham os pontos negativos } \\
\text { com seus familiares e amigos. }\end{array}$ \\
\hline
\end{tabular}

ZEVENBERGEN, H.; de BREE A.; ZEELENBERG, M.; LAITINEN, K.; van DUIJN, G.; FLÖTER, E. Foods with a high fat quality are essential for healthy diets. Annals of Nutrition and Metabolism, v.54, (suppl 1), p.15-24, jul. 2009Fonte: própria autoria

Com o desenvolvimento da tecnologia, o fácil acesso à internet como fonte de pesquisa aumenta a capacidade de atingir indivíduos através do marketing (KOTLER, 2010). Os consumidores passaram a se ajudar pela formação de grupos nas redes sociais, etc., para avaliação de produtos e serviços, tornando os consumidores cada vez mais críticos (TORRES, 2009) 
O marketing de relacionamento é baseado nas experiências de compras anteriores e nas recomendações de outras pessoas (COBRA, 2009). As empresas buscam um relacionamento sólido e duradouro com seus consumidores porque entendem ser mais fácil construir relacionamentos de confiança, na busca pela lealdade dos consumidores do que adquirir novos (SINGH; SIRDESHMUKH, 2000).

Kotler, Kartajaya, Setiawan (2016) afirmaram que o consumidor tem uma relação extremamente pessoal com os produtos e os serviços que adquire, vendo a marca como parte integral de sua vida e de seus valores. A marca simboliza seus valores pessoais e transmite para a sociedade a imagem que o consumidor deseja construir sobre si mesmo.

Diante deste contexto, faz-se indispensável um olhar detalhado dos pontos de insatisfação do consumidor para sempre proporcionar uma boa experiência de consumo, já que de acordo O'Brien (2009) e Robinson e Eskin, (2000) por serem compostas predominantemente por matéria-prima oleosa, as margarinas podem passar por transformações durante o armazenamento, que levam a deterioração da qualidade.

\subsection{Margarina}

A margarina teve sua origem na época de imperador Napoleão III, que por meio de um concurso pediu que fosse desenvolvido um novo produto com as mesmas características da manteiga, porém mais barato e de fácil conservação. O prêmio deste concurso foi para um químico francês, chamado Hippolyte de Mége Mouriés, que patenteou o produto originado do sebo bovino e deu o nome de "óleomargarina" (CHRYSAN, 2005; OLIVER; MACGILL, 1987).

Segundo o Ministério da agricultura, portaria $n^{\circ} 372$ de 04/09/1997, "margarina é um produto gorduroso em emulsão estável elaborado com leite ou seus constituintes ou derivados, e outros ingredientes, destinados à alimentação humana com cheiro e sabor característico. A gordura láctea, 
quando presente não deverá exceder a $3 \%(\mathrm{~m} / \mathrm{m})$ do teor de lipídios totais. Teor máximo de lipídios de 95\%" (BRASIL, 1997).

A Figura 1 detalha a penetração de mercado de spreads no Brasil, entre os anos 2011 a 2015.

Figura 1: Penetração de Spreads (produtos espalháveis) no Brasil (\%)

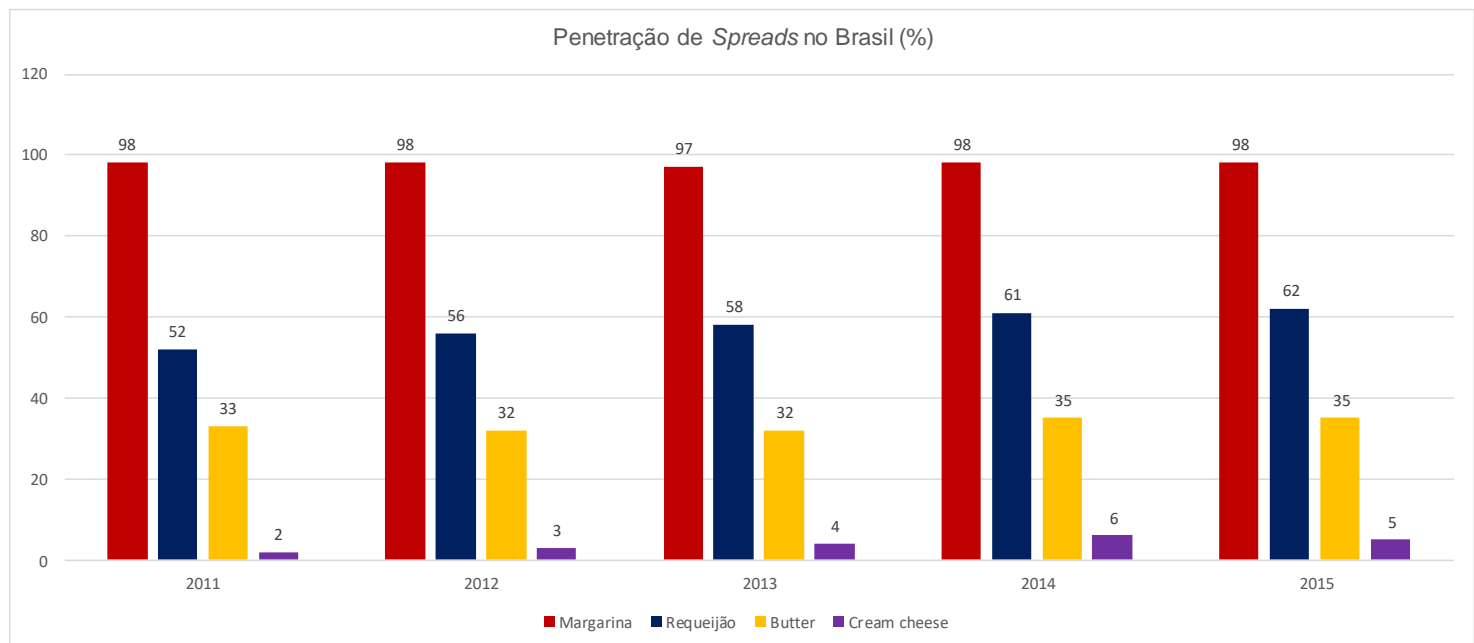

Fonte: Kantar Worldpanel, 2015

Dados do Kantar Worlpanel (2019) mostram que a margarina ainda tem alta penetração. Está presente nas compras de abastecimento, feitas para encher a dispensa e, nas compras de reposição que são realizadas periodicamente pelo consumidor. A margarina está fortemente presente nas compras de abastecimentos de supermercados e atacarejos com ticket médio de $R \$ 146,28$ das regiões norte, nordeste, sul, leste, interior do Rio de Janeiro e também nas compras de reposição com ticket médio de $R \$ 49,72$ das regiões norte, nordeste, grande São Paulo e Sul.

De acordo com a Figura 2 a categoria de margarina também apresenta alta frequência de compra quando comparado com outros produtos espalháveis. 
Figura 2: Frequência de compra de margarinas, quando relacionado com outros produtos espalháveis (Número de compra/Ano)

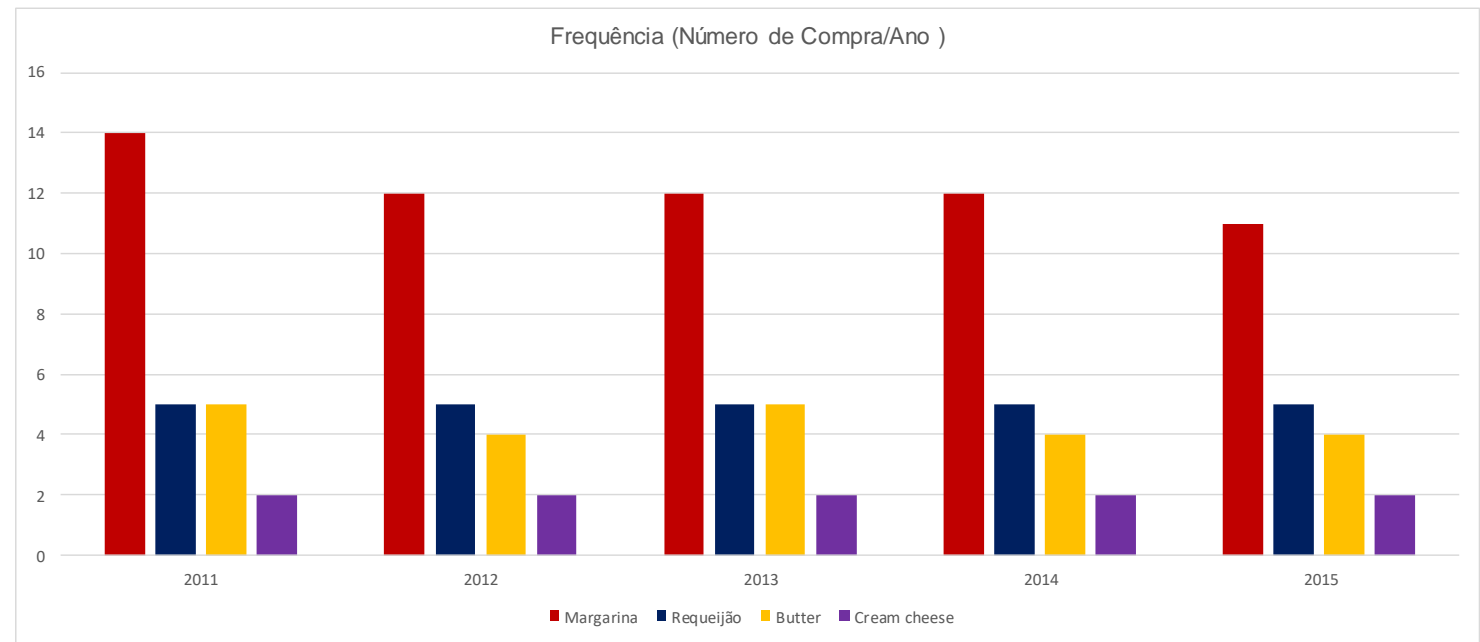

Fonte: Kantar Worldpanel, 2015

Dados do Valor Econômico (2019) demonstram que a frequência de compra continua em queda, devido ao menor tempo e disponibilidade dos consumidores, o que não reduziu o volume médio de compras, já que os consumidores estão comprando o mesmo volume em um menor número de compras.

Mesmo ainda sendo um produto facilmente encontrado nas casas dos consumidores brasileiros, de acordo com Valor econômico (2019), a margarina apresentou cerca de $5 \%$ de queda nas vendas devido a percepção do consumidor de um produto não saudável.

\subsection{Processo Produtivo de Margarina}

A margarina possui propriedades é uma emulsão de água em óleo, que consiste em pequenas gotas de água dispersas em uma fase lipídica contínua, na qual a quantidade de água no produto pode variar de $20 \%$ até 80\% (ZEVENBERGEN et al., 2009). Emulsão pode ser definida como uma mistura de dois líquidos imiscíveis, que se torna estável por ação dos emulsificantes, pois as fases aquosa e oleosa são uniformemente distribuídas uma na outra para que não ocorra separação de fases (RANJITH, 2002). 
Os principais ingredientes que compõem uma margarina são óleos/gorduras, água, leite e derivados, sal, agentes emulsificantes, conservantes, vitaminas, corante e aromatizantes (PERIN, 2018; PEDERSEN, 1994). Sendo indispensável que todos atendam a especificação dos ingredientes.

O processo produtivo da margarina contempla as etapas demonstradas no Fluxograma da Figura 3.

Figura 3: Fluxograma do processo de produção de margarinas

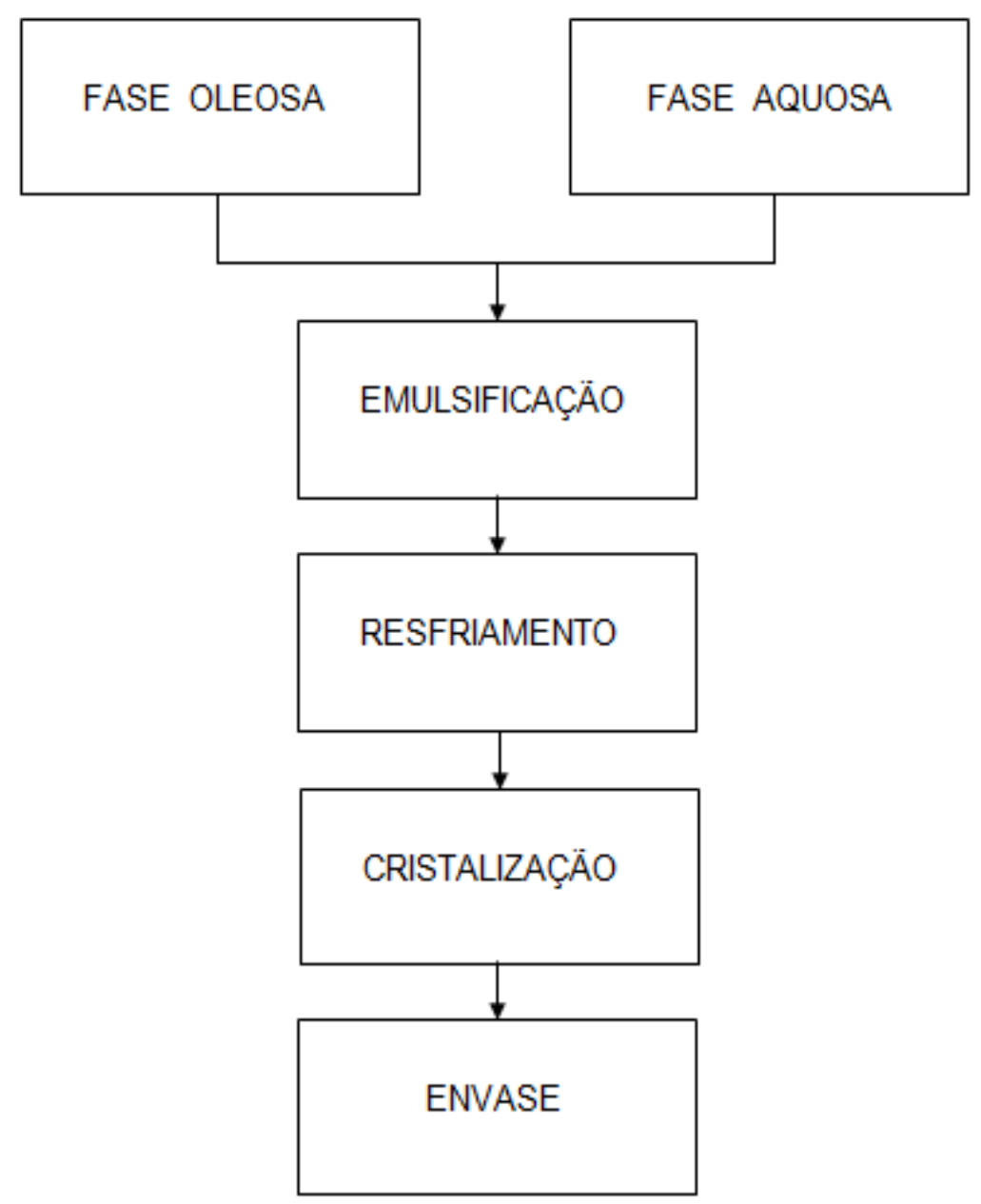

Fonte: SILVA, 2009 


\subsubsection{Preparação das fases aquosa e oleosa}

A fase aquosa consiste na dissolução em água dos ingredientes hidrossolúveis, tais como sal, conservantes, estabilizantes e aromatizantes. Esta fase exerce influência sobre o produto final pois além da função de solubilizar, os ingredientes trazem características específicas e importantes para o produto final. O sal melhora o sabor e previne o crescimento microbiano, o ácido cítrico é responsável por diminuir o pH e age como conservante, e os benzoatos e sorbatos também possuem a função de conservar a margarina. Leite e derivados deixam instáveis emulsões de água em óleo como a margarina, mas são ingredientes importantes na liberação de sabor e aromas (PERIN, 2018; SPX, 2012; RANJITH, 2002, GERSTENBERG SCHODER, 2005)

A preparação da fase oleosa torna-se importante, pois está relacionada com as características do produto final. Nela é necessário escolher os óleos e gorduras que irão compor a margarina e a seleção do óleo irá impactar no ponto de fusão, na consistência, plasticidade e composição de ácidos graxos que irá determinar a resistência à oxidação. A fase oleosa é formada pela mistura de diferentes óleos e gorduras e todos os ingredientes lipossolúveis. Os emulsificantes e os cristais de gordura têm papel fundamental na estabilização das emulsões (PERIN, 2018; SPX, 2012; PEDERSEN,1994; RANJITH, 2002).

\subsection{2. Óleos e Gorduras}

Amplamente utilizados como matéria-prima em alimentos processados, os óleos e as gorduras são do subgrupo dos lipídios. A denominação está associada ao estado físico que a gordura ou óleo se encontram à temperatura ambiente. Os óleos apresentam-se líquidos em temperatura ambiente enquanto as gorduras permanecem semissólidas (MARANGONI; WESDORP, 2013).

Os óleos e gorduras são formados por 96-98\% de triacilgliceróis (TAG) e demais componentes como fosfolipídios, glicolipídios, ácidos graxos livres (AGL), monoacilgliceróis (MAG), diacilgliceróis (DAG), entre outros. Os 
triacilgliceróis (TAGs) são compostos por uma molécula de glicerol associados a três moléculas de ácidos graxos esterificados (LANNES; IGNÁCIO, 2013). As propriedades físicas dos ácidos graxos são função do tamanho da cadeia, grau de saturação, presença de ligações trans, e dependendo das características do produto gorduroso podem interferir na consistência, cristalização, polimorfismo, empacotamento cristalino e perfil de fusão (OLIVEIRA et al, 2016).

As gorduras utilizadas em margarinas são obtidas de processos de hidrogenação ou interesterificação de óleos. Fatores como consistência e estabilidade da emulsão de margarinas estão diretamente relacionados com a fração da gordura cristalizada (CHRYSAM, 2005).

\subsection{3. Óleo de Palma}

O óleo de palma tem grande relevância no mercado, pela sua versatilidade e funções benéficas na qualidade dos produtos. Ele é extraído do fruto da palmeira (Elaeis guineensis Jacq), proveniente da África do Sul. O óleo é naturalmente composto por $50 \%$ de ácidos graxos saturados e $50 \%$ de ácidos graxos insaturados (SOARES et al, 2009).

A tendência dos óleos e gorduras cristalizarem na forma $\beta$ ou $\beta^{\prime}$ está relacionado com o percentual de ácido palmítico. Existe uma tendência de cristalização na forma $\beta$ quando apresentar $10 \%$ ou menos de ácido palmítico, a cristalização $\beta$ ' tendem ocorrer em óleos com $20 \%$ de ácido palmítico ou mais (WEIDERMANN, 1978).

Devido às suas propriedades físico-químicas, a estearina de palma é muito utilizada na interesterificação com óleos vegetais como soja, canola, milho e girassol, pois possuem elevado ponto de fusão, baixa plasticidade, fusão incompleta na temperatura do corpo e contribuem para a dureza desejável (SOARES et al., 2009).

\subsubsection{Gorduras Láuricas}

As propriedades físicas e a resistência à oxidação fazem as gorduras láuricas terem alta empregabilidade na indústria cosmética e 
alimentícia. As principais gorduras láuricas são óleo de coco e óleo de palmiste (GUNSTONE, 2006).

O óleo de coco é extraído do fruto da palmeira Cocos nucifera L., é composto predominantemente por ácidos graxos insaturados (cerca de 90\%), sendo que o ácido láurico representa $45-50 \%$, ácido caprílico de 4 a $10 \%$, cáprico de 5 a $8 \%$, mirístico de 16 a 12\%, palmítico de 8 a 10\%, esteárico de2 a $4 \%$, oléico de 5 a $10 \%$ e linolênico de 1 a 3\% (LANNES; IGNÁCIO, 2013; GUNSTONE, 2006).

O óleo de coco possui sabor suave, odor agradável alta resistência à oxidação, estreita faixa de temperatura que permite mudar repentinamente do estado sólido para o estado líquido (BHATNAGAR et al, 2009). De acordo com Timms (1984) o óleo de coco apresenta apenas uma forma polimórfica estável na forma $\beta$ '.

\subsection{5. Óleo Palmiste}

O óleo de palmiste é extraído da amêndoa do fruto da palmeira Elaeis guineensis e classifica-se como gordura láurica devido ao alto conteúdo de ácido láurico (48\%) na sua composição, além dos ácidos mirístico (16\%) e ácido oleico (15\%). O óleo palmiste é sólido a temperatura ambiente, mas funde-se completamente a temperaturas inferiores que a corporal (CODEX, 2004, KELLENS et al, 2007). O palmiste é amplamente aplicado em margarinas, apresenta rede cristalina na forma $\beta$ ', são estáveis a oxidação, possuem baixo custo, são termicamente estáveis e possuem plasticidade na temperatura ambiente (GOLD, IKHUN, AKOH, 2011; KIM, LUMOR, AKOH, 2008; AINI et al, 2007).

\subsubsection{Preparo da Emulsão}

Consiste na homogeneização de dois líquidos imiscíveis, fases oleosa e aquosa. Primeiramente há a adição de emulsificante no óleo, este 
ingrediente possibilita quimicamente a mistura entre as fases. Só então ocorre a adição da fase aquosa para a formação da emulsão (SPX, 2012; JONHS, 2009; PEDERSEN, 1994;).

Nesta etapa os ingredientes lipossolúveis primeiramente são pesados e enviados para um tanque com agitação (fase oleosa) sendo mantido sob temperatura de 43 a $49^{\circ} \mathrm{C}$. A temperatura é um importante parâmetro neste processo, pois a redução da temperatura pode ocasionar na formação de nucleação dos cristais e de estruturas cristalinas que podem afetar nas características da margarina. Após ser individualmente preparada a fase aquosa é adicionada à fase oleosa lentamente sob agitação (CHRYSAN,2005).

\subsubsection{Resfriamento e cristalização}

Após o aquecimento a emulsão é enviada para trocadores de calor de superfície raspada para que ocorra o resfriamento acelerado. $O$ processo de cristalização se inicia nas paredes do tubo do trocador de calor, este processo favorece a formação de cristais de gordura tipo $\beta^{\prime}$ que em repouso pode se transformar em $\beta$ (PEDERSEN, 1994).

O resfriamento da emulsão dá início ao processo de cristalização. O processo de refrigeração interfere na emulsão (PEDERSEN, 1994), se a velocidade da rotação estiver alta resultará em emulsão com partículas menores e, se a rotação ocorrer em velocidades baixas serão formadas partículas menores do que em velocidades muito baixas (HEERTJE et al., 1988).

A margarina resfriada apresenta estado semissólido e alta viscosidade, passa ainda pelo cristalizador onde, sob a ação mecânica há um aumento de 2 a $3^{\circ} \mathrm{C}$ na temperatura devido a liberação do calor latente da cristalização. A agitação é importante nesta etapa final de solidificação pois auxilia na formação de cristais finos e discretos que distribuem o calor latente uniformemente. Para SPX (2012) durante a cristalização forma-se uma rede tridimensional de cristais de gordura que retém as gotas de água e o óleo, resultando em produtos semissólidos com propriedades de natureza plástica 
A cristalização de gorduras ocorre em três etapas: nucleação, crescimento dos cristais e amadurecimento. A nucleação é a etapa mais importante, pois envolve a formação de aglomerados de moléculas, que estão relacionados com a estabilidade, ou seja, existe uma relação diretamente proporcional entre o aumento da agregação entre as moléculas e o aumento da estabilidade (DOUAIRE et al, 2014; HERRERA et al., 1998; TIMMS, 1995; TORO et al., 2000,).

Nesta etapa os cristais de gordura interagem uns com os outros para formar as redes cristalinas tridimensionais que dão à emulsão as características duras, sólidas (TANG; MARANGONI, 2007). Um cristal pode ser definido como um material no estado sólido capaz de formar redes cristalinas entre moléculas, íons e átomos, em um arranjo ordenado de partículas. Os cristais de gordura são classificados como $\alpha, \beta^{\prime}$ e $\beta$ de acordo com a sua subcélula, que é a menor unidade espacial de repetição ao longo do eixo de uma cadeia alquila dentro de uma unidade de célula (MARANGONI, WESDORP, 2013; METIN; HARTEL, 2005; MARANGONI; NARINE; MARANGONI, 1999; ROUSSEAU et al., 1996).

O polimorfismo dos lipídios é a habilidade de uma substância cristalizar em diferentes formas espaciais, mantendo sua composição química, esta transformação depende de fatores como composição dos ácidos graxos, condições de cristalização, taxa de resfriamento, temperatura e agitação. De um modo geral esta alteração da forma irá impactar no perfil de fusão e solidificação, na morfologia, no tamanho e na agregação cristalina, fatores que estão relacionados com características macroscópicas dos alimentos (SAADI, 2014; METIN; HARTEL, 2005; SATO, 2001;).

A forma a é metaestável, ou seja, irá se transformar em uma forma mais estável $(\alpha \rightarrow C)$, assim como os cristais $\beta^{\prime}$ e $\beta$ apresentam polimorfismo monotrópico também tendem a fazer a transição para forma mais estável quando ocorre uma transição (de $\beta$ ' para $\beta$ ), o empacotamento das cadeias moleculares do triacilglicerol se torna mais compacto, resultando em maior ponto de fusão (NARINE; MARANGONI, 1999; ROUSSEAU et al., 1996; MARANGONI, 2005). 
De acordo com as características do produto pode ser desejável o polimorfismo da forma $\beta$ ' ou $\beta$, em um molho de salada, por exemplo, onde a dimensão física previne a sedimentação dos cristais, a forma $\beta$ é mais eficaz, porém na maioria das aplicações são desejáveis gordura na forma $\beta$ ', principalmente para aplicação em produtos gordurosos, como a margarina, pois oferecem maior plasticidade e maciez ao produto devido à presença de cristais pequenos (GARTI, 2001)

Para atingir as características adequadas para o consumidor, em produtos com alto teor de lipídios como margarinas, por exemplo, é necessária uma quantidade adequada entre as frações sólidas e líquidas para atingir uma boa textura. Outros aspectos como consistência e espalhabilidade, que são importantes para o consumidor, também estão diretamente relacionadas as transformações do óleo. Muitos dos atributos sensoriais, como espalhabilidade, sensação na boca e textura são dependentes da resistência mecânica da rede cristalina (DOUAIRE, et al., 2014; PISKA et al., 2006; O'BRIEN, 2009; TOROVASQUEZ et al., 2000;).

Fusão e cristalização são as propriedades térmicas de maior interesse em gorduras, pois estão relacionadas com as características polimórficas da gordura e com o teor de gordura sólida. Após o processo térmico a gordura pode apresentar diversas fases de fusão, sendo que cada etapa de recristalização representa a transição de uma forma polimórfica menos estável para uma mais estável. Um identificador do formato polimórfico de um cristal pode ser a temperatura na máxima medida durante a transformação do cristal. O cristal de gordura com a temperatura de fusão mais elevada também é o que possui maior estabilidade (BECKER-ALMEIDA, 2008).

DeMAN e BLACKMAN (1995) relataram que o efeito do tempo na morfologia cristalina da margarina envolveu mudanças da forma $\beta$ ' para $\beta$ e a textura dependia do histórico de temperatura da emulsão. Liu et al (2010) relataram que as mudanças das propriedades físicas das margarinas são influenciadas pelo tratamento térmico. 


\subsubsection{Envase}

A embalagem tem a função de proteger a margarina durante o transporte e vida de prateleira. Geralmente as margarinas são envasadas em potes plásticos com características de barreiras de proteção à luz e ao oxigênio, sendo o polipropileno muito utilizado (ALEXANDERSEN, 2005; BOCKISCH, 2015).

\subsection{Importância do processo de produção na qualidade do produto final}

A formulação e as interações dos ingredientes, composição do óleo assim como o processo produtivo podem afetar a qualidade da margarina (WIEDERMANN, 1978).

De acordo com Wassel (2005) os principais problemas em margarinas que estão diretamente relacionados com seu processo produtivo (Tabela 1).

\subsection{Principais alterações da margarina durante a estocagem}

A vida de prateleira da margarina está relacionada com as alterações sensoriais, químicas, físico-químicas e microbiológicas em consequência de falhas no processo produtivo, seleção e quantidade inadequada dos ingredientes e matéria-prima utilizados e condições de estocagem. As alterações como quebra de emulsão com separação de óleo e/ou água, alterações de cor, espalhabilidade, sabor e odor são facilmente percebidas pelo consumidor (McCLEMENT, 2012; CHRYSAN, 2005;). 
Tabela 1: Problemas que podem ocorrer no processo de margarina

\begin{tabular}{|c|c|c|}
\hline Etapa do processo & Causa & Efeito na margarina \\
\hline \multirow[b]{2}{*}{ Cristalização } & Excesso de cristalização & $\begin{array}{l}\text { Cremosidade excessiva, } \\
\text { brilho excessivo, aspecto } \\
\text { seboso/oleoso }\end{array}$ \\
\hline & Falta de cristalização & $\begin{array}{l}\text { Baixa cremosidade/ } \\
\text { espalhabilidade, aspecto } \\
\text { quebradiço, presença de } \\
\text { grumos }\end{array}$ \\
\hline \multirow[b]{2}{*}{ Emulsificação } & Temperatura do tanque & $\begin{array}{l}\text { Pode ocasionar a } \\
\text { separação da água da } \\
\text { margarina quando } \\
\text { espalhada }\end{array}$ \\
\hline & $\begin{array}{l}\text { Adição muito rápida da } \\
\text { fase aquosa durante a } \\
\text { emulsificação e /ou } \\
\text { agitação insuficiente no } \\
\text { tanque de emulsão }\end{array}$ & $\begin{array}{l}\text { Pode desestabilizar a } \\
\text { emulsão e levar a } \\
\text { separação de fase. }\end{array}$ \\
\hline \multirow{2}{*}{$\begin{array}{l}\text { Parâmetros de } \\
\text { qualidade }\end{array}$} & $\begin{array}{l}\text { Higienização ineficiente } \\
\text { dos equipamentos }\end{array}$ & $\begin{array}{l}\text { Pode ocorrer contaminação } \\
\text { por microrganismos. }\end{array}$ \\
\hline & $\begin{array}{l}\text { Variação na temperatura } \\
\text { de armazenagem do } \\
\text { produto acabado }\end{array}$ & $\begin{array}{l}\text { Pode gerar quebra da } \\
\text { emulsão }\end{array}$ \\
\hline
\end{tabular}

Fonte: Wassel (2005)

\subsubsection{Alterações microbiológicas}

A margarina é formada por uma rede de pequenos cristais de gordura, sendo uma estrutura de gotículas de água em óleo. Os microrganismos são capazes de se desenvolver de acordo com a disponibilidadede nutrientes, do $\mathrm{pH}$ da fase aquosa e do volume da gotícula de água na qual ele está confinado. Existe menor possibilidade dos microsganismos se desenvolverem em emulsões finas, onde os tamanhos das gotículas são menores que $10 \mu \mathrm{g}$ (HOLLIDAY; ADLER; BEUCHAT, 2003).

A margarina é um alimento considerado seguro devido a falta de ocorrência com problemas de segurança dos alimentos. Os mofos são os microrganismos deteriorantes mais suscetíveis a apresentarem crescimento 
neste tipo de produto. Fatores como tamanho das gotículas da fase aquosa, adição de sal, adição de conservantes e boas práticas de fabricação mitigam o crescimento microbiano de deteriorantes e patógenos (DELAMARRE; BATT, 1999).

O crescimento de microrganismos que produzem a enzima lipase podem contribuir na liberação de sabores indesejados, devido a hidrólise da gordura que libera ácidos graxos na margarina. Este tipo de alteração tem baixo histórico de incidência (CHARTERIS,1996).

\subsubsection{Alterações fisico-químicas}

Parâmetros como consistência e estabilidade da emulsão da margarina dependem das propriedades da rede cristalina da gordura. Os triacilglicerídeos nas suas formas primárias são denominados $\alpha, \beta$, $\beta$. A forma $\alpha$ é pouco estável e rapidamente se transforma em $\beta^{\prime}$ formando uma rede de cristais. Sua área superficial imobiliza grande quantidade de gotículas na fase oleosa e na fase aquosa. Os cristais produzidos na forma $\beta^{\prime}$ podem se transformar em $\beta$ sob certas condições de estocagem, dependendo da tendencia do tipo da gordura utilizada em cristilizar na forma $\beta$ (CHRYSAN, 2005).

A forma $\beta$ é a mais estável do cristal de gordura e apresenta maior ponto de fusão. Como este tipo de cristais são grandes trazem características como textura arenosa podendo resultar em separação de fase da margarina (CHRYSAN, 2005).

\subsubsection{Alterações químicas}

Óleos e gorduras são sensíveis a três tipos de rancidez: oxidativa, hidrolítica e cetônica. A rancidez oxidativa é ocasionada pela oxidação de triacilglicerois insaturados e de ácidos graxos presentes nos óleos e gorduras. Este processo é desencadeado pela autoxidação, fotoxidação ou oxidação causada pela enzima lipoxigenase (SOUTHWEEL; HARRIS; SWETMAN, 1996). 
A autoxidação ocorre quando há reação entre o oxigênio e os lipídios insaturados envolvendo os radicais livres de iniciação, propagação e terminação. O radical livre de lipídio reage com os lipídios insaturados formando radical livre de peróxido. O radical livre reage com mais lipídios insaturados, processo de propagação, onde sao formados os hidroperóxidos que são os componentes primários da autoxidação. A terminação pode ser ocasionada pela combinação de dois radicais entre si, formando compostos mais estáveis. Os óleos ricos em ácido oleico (18:1), ácido linoleico (18:2) e ácido linolênico (18:3), estão mais propensos ao processo de autoxidação devido a maior disponilidade de insaturações ao longo da cadeia da molécula, que aumenta a tendência da reação química acontecer (SOUTHWEEL; HARRIS; SWETMAN, 1996).

A rancidez hidrolítica comumente ocorre em gorduras láuricas e não em óleos insaturados de cadeias longas. Este processo decorre da formação de ácidos graxos livres produzidos pela hidrólise de triglicerídeos em presença da enzima lipase, de fermento ou de mofo. A liberação de ácidos graxos láuricos, como Cáprico (10:0), Láurico (12:0) e Mirístico (14:0) podem acarretar em sabor saponáceo (SOUHWEEL; HARRIS; SWETMAN, 1996).

A rancidez cetônica é a menos comum, neste processo há liberação e oxidação de ácidos graxos de cadeia curta de gorduras láuricas. Os ácidos graxos de cadeia média são hidrolisados por fungos filamentosos do gênero Penicilium, Aspergillus, Clodosporium, Fusarium Trichoderma e Monascus, gerando inicialmente ácidos graxos menores até que se tranformem em cetonas e álcoois alifáticos (KINDERLERER, 1994; MACFARLANE, 2001) O radical livre de lipídio reage com os lipídios insaturados formando radical livre de peróxido.

Umas das principais reações de deterioração em lipídios é a oxidação e implica no surgimento de sabores e odores (conhecido como ranço). Essa reação causa redução do valor nutricional, como resultado da perda de ácidos graxos essenciais, limitando a vida útil de muitos alimentos. Substâncias capazes de inibir ou retardar a oxidação são geralmente adicionadas a óleos, gorduras e alimentos gordurosos e estes antioxidantes 
são eventualmente capazes de prolongar a vida útil de alimentos (ANDREO et al., 2006).

\subsection{Entendendo o comércio varejista}

O mercado varejista é responsável pela intermediação entre indústria e consumidor final. $\mathrm{O}$ varejo disponibiliza e vende diversos produtos de maneira acessível para os compradores, conhecido como (autosserviço), onde o consumidor escolhe o que mais lhe convir e na saída são direcionados para os caixas para o registro e finalização da compra (CERIBELI, 2011 e CLEMENTE, 2003). O varejo alimentício pode ser classificado conforme demonstrado no Quadro 2.

Quadro 2: Classificação de tipos de comércios varejistas:

\begin{tabular}{|l|l|}
\hline $\begin{array}{c}\text { TIPOS DE COMÉRCIO } \\
\text { VAREJISTAS }\end{array}$ & \multicolumn{1}{|c|}{ DESCRIÇÃO } \\
\hline Minimercados & $\begin{array}{l}\text { Possuem baixa variedade de produtos e geralmente } \\
\text { estão localizados nas periferias das cidades. Possuem } \\
\text { área de } 50 \text { a } 250 \mathrm{~m}^{2} \text {. }\end{array}$ \\
\hline$\underline{\text { Lojas de conveniência }}$ & $\begin{array}{l}\text { Apresentam a mesma área dos minimercados, porém } \\
\text { diferenciam-se devido aos preços elevados e pelo } \\
\text { horário de atendimento estendido. Oferecem produtos de } \\
\text { mercearia, frios, laticínios, bazar e lanches }\end{array}$ \\
\hline$\underline{\text { Supermercados }}$ & $\begin{array}{l}\text { Possuem linhas completas de produtos, porém baixa } \\
\text { variedade de marcas em comparação às grandes lojas. } \\
\text { Possuem área total de } 300 m^{2} \text { a } 700 m^{2} \text {, com 2 a } 6 \text { caixas. }\end{array}$ \\
\hline$\underline{\text { Supermercados }}$ & $\begin{array}{l}\text { estabelecimentos de porte médio com área total que } \\
\text { varia de } 700 \text { a } 2,5 \text { mil m }{ }^{2} \text { e com } 7 \text { a 29 caixas, onde é } \\
\text { possível encontrar boa variedade de produtos. }\end{array}$ \\
\hline$\underline{\text { Superlojas }}$ & $\begin{array}{l}\text { Lojas com grande sortimento de produtos alimentícios, } \\
\text { possuem mais de } 29 \text { caixas e área de mais } 4 \text { mil m². Sua } \\
\text { área permite a exposição e venda de produtos para o lar } \\
\text { e eletroeletrônicos. }\end{array}$ \\
\hline$\underline{\text { Hipermercado }}$ & $\begin{array}{l}\text { São caracterizados pela grande variedade de produtos } \\
\text { alimentícios, não alimentícios e preços reduzidos, com } \\
\text { área de aproximadamente } 10 \text { mil m². }\end{array}$ \\
\hline$\underline{\text { Atacadistas }}$ & $\begin{array}{l}\text { Devido ao seu espaço amplo normalmente estão } \\
\text { localizados em regiões mais afastadas, possuem bons } \\
\text { preços e realizam a venda tanto para restaurantes, } \\
\text { comerciantes e consumidores final (atacado e varejo). }\end{array}$ \\
\hline
\end{tabular}

Fonte: Ceribeli, 2011; Bernardino 2004; Clemente, 2003; Parente, 2000. 
Como a margarina é um produto de consumo diário e está presente em $97 \%$ dos lares brasileiros não é difícil encontrá-la nos diversos tipos de canais de distribuição. Sugere-se que em pequenos canais de distribuição as margarinas estarão mais suscetíveis às oscilações de temperatura devido a necessidade de boas instalações e consequentemente investimentos em manutenção preventiva das gôndolas de estocagem. Também é indispensável que os pontos de vendas mantenham as gôndolas ligadas durante o dia e a noite para que haja manutenção da temperatura e tenham espaço para armazenar $100 \%$ das caixas de margarina em locais refrigerados após o recebimento.

\subsection{Análise Sensorial}

O papel da análise sensorial na indústria de alimentos torna-se cada vez mais forte, pois não basta apenas que um produto atenda a qualidade microbiológica, química, física, mas é indispensável que o produto atenda às necessidades e expectativas do consumidor (MINIM, 2006)

A análise sensorial na indústria de alimentos surge para construir um elo entre investigação e o desenvolvimento de produtos, fornecendo informações indispensáveis no entendimento da aceitação dos consumidores, pela compreensão, medição, análise e interpretação das respostas humanas aos alimentos, usando como instrumento de medida os sentidos da visão, do olfato, do tato, do paladar e da audição (LAWLESS, HEYMANN, 2013; ABNT 5492:2008, STONE; SIDEL, 2004,).

As características sensoriais são importantes para a qualidade do produto e precisam ser avaliadas durante toda vida útil do produto que vai desde a sua produção até o monitoramento durante a estocagem.

Reologia é a ciência que estuda o fluxo e deformação de sólidos e líquidos sob influência de forças mecânica, e a vários atributos sensoriais podem ser correlacionados com as propriedades reológicas. Esta ciência auxilia na compreensão dos atributos sensoriais de uma emulsão inclusive ao longo da vida útil (IBARZ; RIBAS, 2005; BASTOS, 2013). 
De acordo com Vaisey e Genser (2003) e Freeman e Melnikov, (2015) as características sensoriais de emulsões como as margarinas podem ser classificadas em 4 grupos, aparência, sensação na boca, sabor e gosto. A aparência contempla a avaliação da cor e brilho, assim como a sensação na boca engloba atributos de firmeza e fusão. O gosto e o sabor estão relacionados com gosto salgado, gosto amargo, sabor amanteigado e rançoso.

Existem diversos métodos na análise sensorial, o uso de cada um está relacionado com o objetivo da análise, principalmente com o tipo de resposta que se espera. Assim, a análise sensorial pode ser dividida em métodos descritivos que caracterizam e quantificam e métodos discriminativos que podem diferenciar amostras, e métodos afetivos que servem para medir a aceitação de um produto (CHAVES, 1980; TEIXEIRA et al., 1987; ANZALDÚAMORALES, 1994, DUTCOSKY; 2013).

Os métodos descritivos, os quais serão utilizados neste estudo, são qualitativos pois caracterizam as amostras e, são quantitativos porque trazem a intensidade de cada atributo percebido (DUTCOSKY, 2013; LARMONR, 1977). Estes métodos trazem as diferenças nas intensidades de cada atributo e possibilita saber também se existe diferença entre produtos distintos, através do emprego de escalas (MAGALHÃES, 1996). Nos métodos descritivos, assim como nos demais, os avaliadores são a ferramenta de medição da qualidade (ASTM, 1981)

\subsubsection{Método perfil por consenso}

É um método descritivo que avalia perfil sensorial do produto por meio do consenso dos avaliadores que provam e discutem os produtos determinando os atributos e/ou suas intensidades. Neste método é indispensável um acordo entre os avaliadores nos atributos e intensidades durante as avaliações dos produtos.

No método perfil por consenso os avaliadores provam os produtos e discutem os atributos e/ou intensidades para determinar uma descrição acordada do produto em questão. $O$ consenso requer que 0 acordo seja alcançado em vez de calcular a média dos dados no grupo. Em métodos de 
consenso, o painel tem poucos avaliadores (4 a 4 ) que devem ser extensivamente treinados para determinar propriedades e tomar decisões sobre os atributos e intensidades à medida que provam (ABNT 13299:2017).

O conhecimento e aptidão dos avaliadores são fatores imprescindíveis. Quando um o avaliador tem alta capacidade de concentração, não é influenciável, avalia com frequência um único produto e demonstra aptidão para análise sensorial, pode ser considerado um expert ou especialista. Este tipo de avaliador possui alta acuidade, alta reprodutibilidade devido a memória sensorial de longo prazo que permite resultados confiáveis mesmo sem referência ou controles (ABNT 8586:2016).

Ainda de acordo com a ABNT 8586:2016, a memória sensorial do expert ou especialista é acima da média para conseguir manter as características sensoriais a curto e a longo prazo. Sendo possível correlacionar atributos sensoriais com experiências adquiridas durante o treinamento.

Já, de acordo com a mesma ABNT 8586 (2016) os avaliadores sensoriais selecionados são aqueles com habilidade de realizar testes sensoriais, para serem experts, porém ainda precisam passar pelas etapas de treinamento e monitoramento do desempenho.

O treinamento sensorial é voltado para um produto específico e tem o objetivo de aprimorar o conhecimento técnico de cada avaliador selecionado e consequentemente é indispensável escolher o foco do painel treinado pois pode ser aplicado em testes descritivos ou discriminativos (ABNT 8586:2016).

$\mathrm{Na}$ etapa de monitoramento do desempenho os avaliadores participam de vários testes sensoriais onde é exigida boa repetibilidade inter e intrassessão para ser considerado um avaliador expert (ABNT 8586:2016). 


\section{MATERIAL E MÉTODO}

\subsection{Amostras}

O produto avaliado foi constituído de margarinas produzidas por uma empresa do setor alimentício com representatividade na produção de margarina no Brasil, e que se destaca no mercado pela sua vasta gama de produtos em comercialização e pela preocupação com a segurança dos alimentos em todas da cadeia produtiva, e que doravante será chamada como Empresa "A". As margarinas avaliadas pertencem todas da mesma marca, a qual constitui um importante produto da empresa.

As margarinas foram produzidas de acordo com as boas práticas de fabricação e de acordo com parâmetros de processo de forma a garantir a qualidade do produto final.

A margarina estudada continha os ingredientes constantes na rotulagem da embalagem e apresentadas no Quadro 03.

\subsubsection{Obtenção das margarinas nos pontos de vendas}

Cinquenta e cinco margarinas do mesmo lote (mesma data e horário de fabricação) foram avaliadas em dois momentos:

- Controle: avaliação descritiva realizada no tempo zero, antes do produto ser submetido às condições de estocagem no ponto de venda, temperatura de armazenamento e avaliação a $8^{\circ} \mathrm{C}$.

- Ponto de venda: avaliação descritiva das margarinas coletadas dos pontos de venda. No momento da compra foi medida a temperatura do produto com um termômetro digital infravermelho. Independente da temperatura no momento da compra, todas as amostras foram armazenadas no laboratório em geladeira até o momento da avaliação sensorial nas mesmas condições para garantir que no momento da avaliação estivessem na temperatura de 8 a $10^{\circ} \mathrm{C}$.

Desta forma foram avaliadas ao todo 110 (cento e dez) amostras de margarinas, sendo 55 (cinquenta e cinco) pares "Controle" versus "Ponto de Venda". 
As margarinas foram compradas em canais de distribuição pequenos, com no máximo 9 caixas para pagamento, definidos como minimercados, supermercados compactos e supermercados convencionais das regiões centro-oeste e sudeste do Brasil, devido a maior representatividade de consumo do produto nestas regiões.

Quadro 3: Informações constantes no rótulo da embalagem da margarina estudada.

\begin{tabular}{|l|l|}
\hline \multirow{3}{*}{ Ingredientes } & $\begin{array}{l}\text { Óleos de soja } \\
\text { Gordura vegetal } \\
\text { Água } \\
\text { Sal (cloreto de sódio) } \\
\text { Soro de leite em pó } \\
\text { Leite em pó desnatado } \\
\text { Vitaminas B (B6, B1 e B12) } \\
\text { Vitamina A, }\end{array}$ \\
\hline Estabilizantes & $\begin{array}{l}\text { Mono e diglicerídios de ácidos graxos } \\
\text { Lecitina de soja }\end{array}$ \\
\hline Conservantes & $\begin{array}{l}\text { Sorbato de potássio } \\
\text { Benzoato de sódio }\end{array}$ \\
\hline Antioxidantes & $\begin{array}{l}\text { TBHQ } \\
\text { EDTA } \\
\text { BHT } \\
\text { Cálcio dissódico }\end{array}$ \\
\hline Acidulante & Ácido ć́trico \\
\hline Aromatizante & Aroma idêntico ao natural \\
\hline Corantes & $\begin{array}{l}\text { Urucum } \\
\text { Beta caroteno } \\
\text { Cúrcuma }\end{array}$ \\
\hline
\end{tabular}

Fonte: própria autoria 


\subsubsection{Armazenamento das margarinas em condições controladas}

As amostras de margarinas foram armazenadas nas temperaturas de $8^{\circ} \mathrm{C}$, representando a estocagem na casa do consumidor. As margarinas foram armazenadas em estufas FANEM modelo 547 regulada na temperatura de $8^{\circ} \mathrm{C}$. Periodicamente os potes de margarinas foram avaliados de acordo com os atributos sensoriais previamente estabelecidos na empresa "A". Esta avaliação foi realizada até que o produto completasse 180 dias, tempo total previsto para a estocagem da margarina.

\subsubsection{Avaliação das margarinas}

As amostras de quatro lotes diferentes foram avaliadas com diferentes tempos de armazenamento conforme frequência definida na Tabela 2.

Tabela 2: Frequência de avaliação das amostras de margarinas

\begin{tabular}{|c|c|}
\hline Avaliação & Tempo \\
\hline 1‥ Avaliação & Tempo "zero". \\
\hline $2^{\mathrm{a}}$. Avaliação & 45 dias \\
\hline $3^{\text {a }}$. Avaliação & $\begin{array}{c}90 \text { dias (metade do tempo } \\
\text { decorrido do shelf-life } \\
\text { estabelecido) }\end{array}$ \\
\hline 4⿳亠口了. Avaliação & $\begin{array}{c}135 \text { dias ( } 3 / 4 \text { do shelf-life } \\
\text { estabelecido) }\end{array}$ \\
\hline 5a. Avaliação & $\begin{array}{c}180 \text { dias (tempo em que o } \\
\text { produto atinge o shelf-life } \\
\text { estabelecido) }\end{array}$ \\
\hline
\end{tabular}

Fonte: própria autoria 


\subsection{Reclamação dos consumidores}

O estudo foi conduzido inicialmente pelo levantamento das reclamações dos consumidores das margarinas estocadas nos diferentes pontos de vendas, a partir da base de dados da empresa "A", obtidos no Serviço de Atendimento ao Consumidor (SAC) no ano de 2018.

Realizou-se um filtro de acordo com os tipos de reclamações da margarina, dos quais foram posteriormente elencadas as reclamações pertinentes a questões sensoriais, contemplando os atributos de aparência, sabor e textura da margarina. A seguir, as reclamações foram classificadas utilizando-se o Diagrama de Pareto, utilizando-se o software Action Stat Quality®.

$\mathrm{Na}$ sequência, foram realizadas avaliações das características sensoriais das margarinas estocadas em condições controladas de temperatura. Da mesma forma realizou-se avaliação das características sensoriais das margarinas estocadas nos pontos de vendas.

\subsection{Análise sensorial}

O Projeto foi aprovado ao Comitê de Ética em Pesquisa com Humanos (CEPH) da Faculdade de Zootecnia e Engenharia de Alimentos (FZEA/USP), campus Fernando Costa, localizado em Pirassununga/SP, de acordo com o Número do Parecer: 2.247.583. O Termo de Consentimento Livre e Esclarecido (TCLE) é apresentado no Apêndice A. O parecer consubstanciado do CEPH é apresentado no Apêndice $B$.

A empresa "A" possui avaliadores selecionados, constituídos de colaboradores internos que possuem carta de voluntariado devidamente assinada para participação de testes sensoriais. Estes são capacitados de acordo com a ABNT 8586 (2016) e, portanto, familiarizados com as definições e intensidades dos atributos sensoriais da margarina. Foram utilizados quatro avaliadores que pudessem exibir um desempenho consistente e confiável quanto ao uso das escalas para avaliar as intensidades dos atributos das 
margarinas. Estes avaliadores eram constituídos de três do sexo feminino e um do sexo masculino, com idades variando entre 25 a 40 anos.

Em 1981 Chambers et al. já haviam demonstrado a eficiência de pequenas equipes sensoriais, desde que altamente treinadas.

Os quatro avaliadores experts já haviam passado pelas etapas exigidas pelas ABNT 8586(2016):

- Seleção: os avaliadores se tornaram aptos a realizarem testes sensoriais, de acordo com metodologia sugerida pela norma.

- Treinamento: realizado quando os avaliadores selecionados adquiriram embasamento técnico no produto, nos atributos e na escala a serem utilizadas.

- Monitoramento do desempenho: quando os avaliadores foram periodicamente submetidos às análises que checaram seu desempenho na avaliação do produto.

- Tempo de experiência: os avaliadores foram qualificados neste quesito com experiências semanais em avaliações sensoriais de margarina nos atributos e nas escalas, pelo período mínimo de 1 ano.

Estando, portanto, qualificados para realizarem análises de margarina com alto grau de sensibilidade devido a sua consistência e repetibilidade e por isso considerados avaliadores experts ou especialistas.

As avaliações dos especialistas foram realizadas de acordo com duas condições de estudo:

1) Avaliação sensorial periódica das margarinas em condições controladas por até 180 dias de estocagem. Nesta condição foram medidas as alterações da margarina em condições estáveis de estocagem $\left(8^{\circ} \mathrm{C}\right)$, representando $o$ armazenamento na geladeira do consumidor $e$ entendendo as principais alterações nas características sensoriais do produto no ponto zero (que na indústria representa dois dias após a produção) comparativamente com os tempos de 45, 90, 135 e 180 dias, considerando 4 repetições. 
2) Avaliação sensorial das margarinas em condições reais de estocagem, que foram coletadas de pontos de venda nos diversos tempos de vida útil encontrados nos dias da coleta. Foram realizadas 55 coletas em pontos de vendas e cada margarina coletada foi avaliada comparativamente com as contraprovas da mesma data de fabricação que foi avaliada no tempo "zero".

\subsubsection{Método perfil por consenso}

Os quatro experts em margarinas avaliaram cada amostra, pontuando de forma monádica cada atributo de acordo com a escala de 7 pontos: (0) Característica não está presente, (1) Característica é muito leve, (2) Característica é leve, (3) Característica é leve a moderada, (4) Característica é moderada, (5) Característica é moderada a forte (6) Característica é forte, utilizando a ficha de avaliação sensorial mostrada na Figura 4.

Figura 4: Ficha sensorial utilizada durante o estudo sensorial

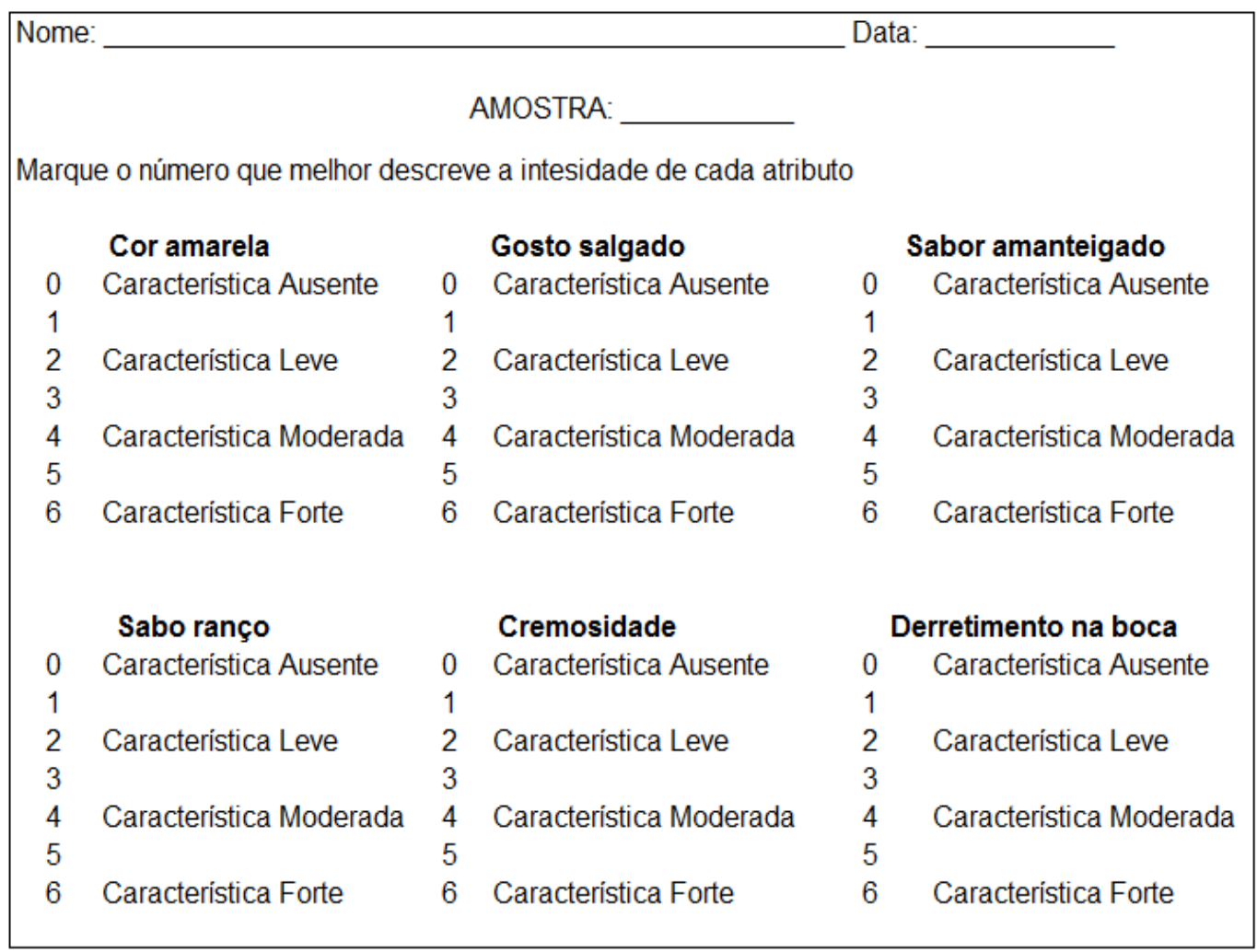

Fonte: própria autoria 
$\mathrm{Na}$ avaliação dos dados foi utilizada a análise de variância (ANOVA) e o teste de Tukey para indicar se existe diferença significativa entre as amostras a $5 \%$ significância.

\section{RESULTADOS E DISCUSSÃO}

\subsection{Reclamações dos consumidores}

No ano de 2018, foram registradas diferentes reclamações dos consumidores, das quais foram avaliadas as relacionadas às características sensoriais, agrupadas em aparência (coloração amarelada), sabor (sabor com pouco sal; sabor muito salgado; sabor; sabor diferente e sabor de ranço), textura (consistência/textura; consistência/textura mole; consistência/textura muito líquida) e outras reclamações (Aspecto, aspecto deslocado, sabor azedo e quantidade falta pedaço). A Figura 5 apresenta o número de reclamações de clientes recebidas pelo SAC da empresa "A" durante o ano de 2018.

Figura 5: Número de reclamações de clientes recebidas pelo SAC da empresa "A" durante o ano de 2018

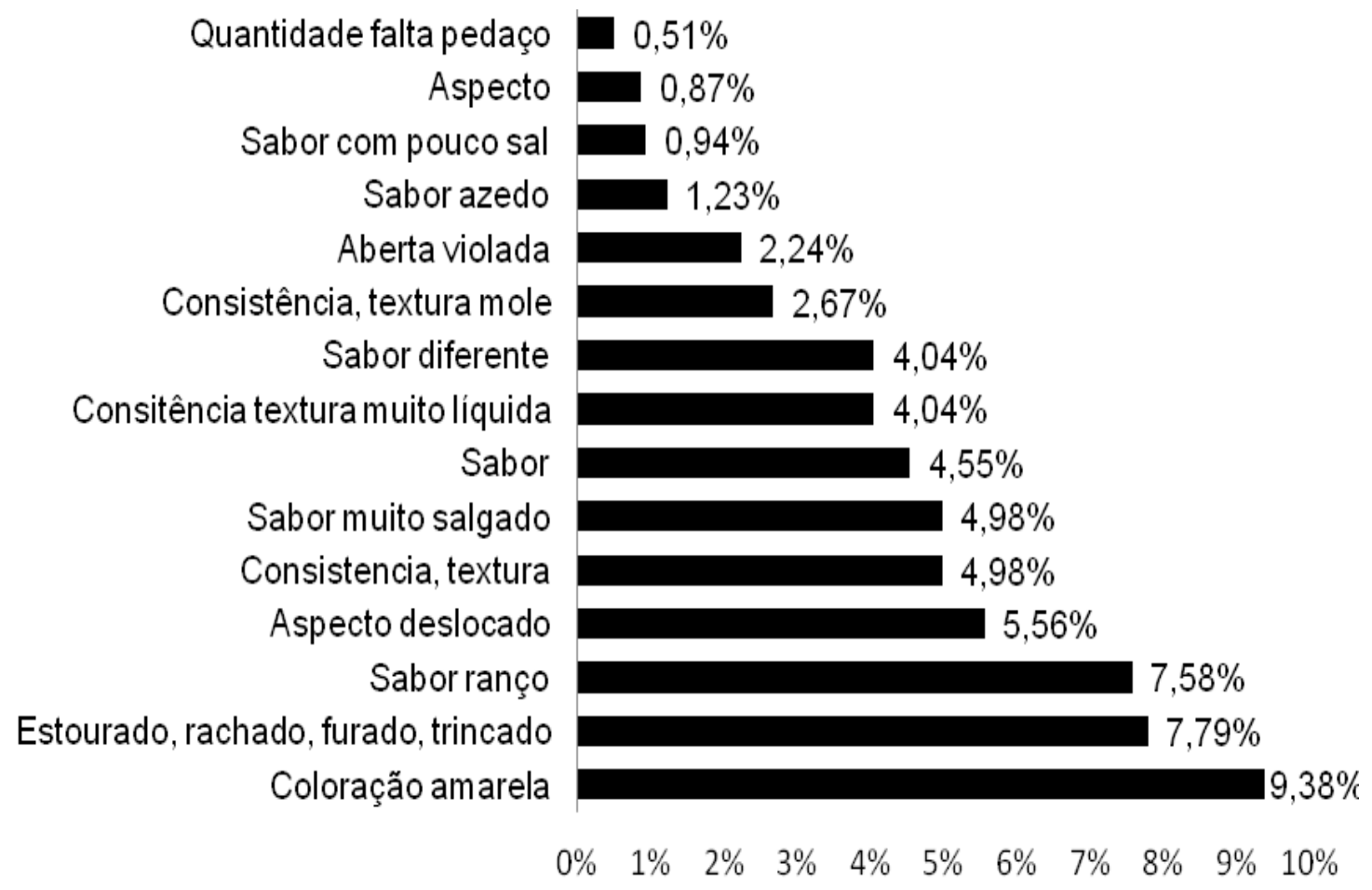

Fonte: Dados obtidos do SAC da empresa "A". 
Do total de reclamações obtidas pelo SAC (Serviço de Atendimento ao Cliente) referentes às margarinas em estudo, $51,3 \%$ estão relacionados com atributos sensoriais, classificadas nos atributos principais (aparência, sabor, textura e outros).

A Tabela 3, apresenta os valores de frequência utilizados para elaborar o Diagrama de Pareto, apresentando o principal problema a ser estudado. Desta forma, pela Figura 6, percebe-se que o principal atributo a ser considerado está relacionado ao sabor sendo responsável por $22,08 \%$ das reclamações, seguida da textura com $11,69 \%$.

Portanto o estudo concentrou-se em avaliar as possíveis causas de reclamações relacionadas ao sabor, agrupadas em sabor com pouco sal; sabor muito salgado; sabor; sabor diferente e sabor de ranço. Para esta categoria fez-se novamente uma análise pelo Diagrama de Pareto (Tabela $4 \mathrm{e}$ Figura 7), chegando-se a conclusão que o principal problema estava relacionado ao sabor de ranço, conforme relatado pelos consumidores.

Assim, resolve-se investigar se o problema com o sabor de ranço poderia estar relacionado com a forma de armazenamento das margarinas, principalmente relacionados com o Ponto de Venda (PDV).

Tabela 3: Frequências relativas dos dados de reclamações obtidas pelo SAC no ano de 2018, relativas às características sensoriais de margarinas

\begin{tabular}{lcccc}
\hline \multicolumn{5}{c}{ Frequências Relativas } \\
\hline Categorias & Frequência & $\begin{array}{c}\text { Frequência } \\
\text { Acumulada }\end{array}$ & Porcentagem & $\begin{array}{c}\text { Porcentagem } \\
\text { Acumulada }\end{array}$ \\
\hline SABOR & 22,08 & 22,08 & 43,04 & 43,04 \\
TEXTURA & 11,69 & 33,77 & 22,79 & 65,83 \\
APARÊNCIA & 9,38 & 43,15 & 18,28 & 84,11 \\
OUTROS* & 8,15 & 51,3 & 15,89 & 100 \\
\hline${ }^{*}$ Aspecto, aspecto deslocado, sabor azedo e quantidade falta pedaço
\end{tabular}


Figura 6: Gráfico de Pareto apresentando a classificação dos principais problemas relacionados aos aspectos sensoriais de margarinas produzidas pela empresa "A", das reclamações obtidas pelo SAC no ano de 2018.

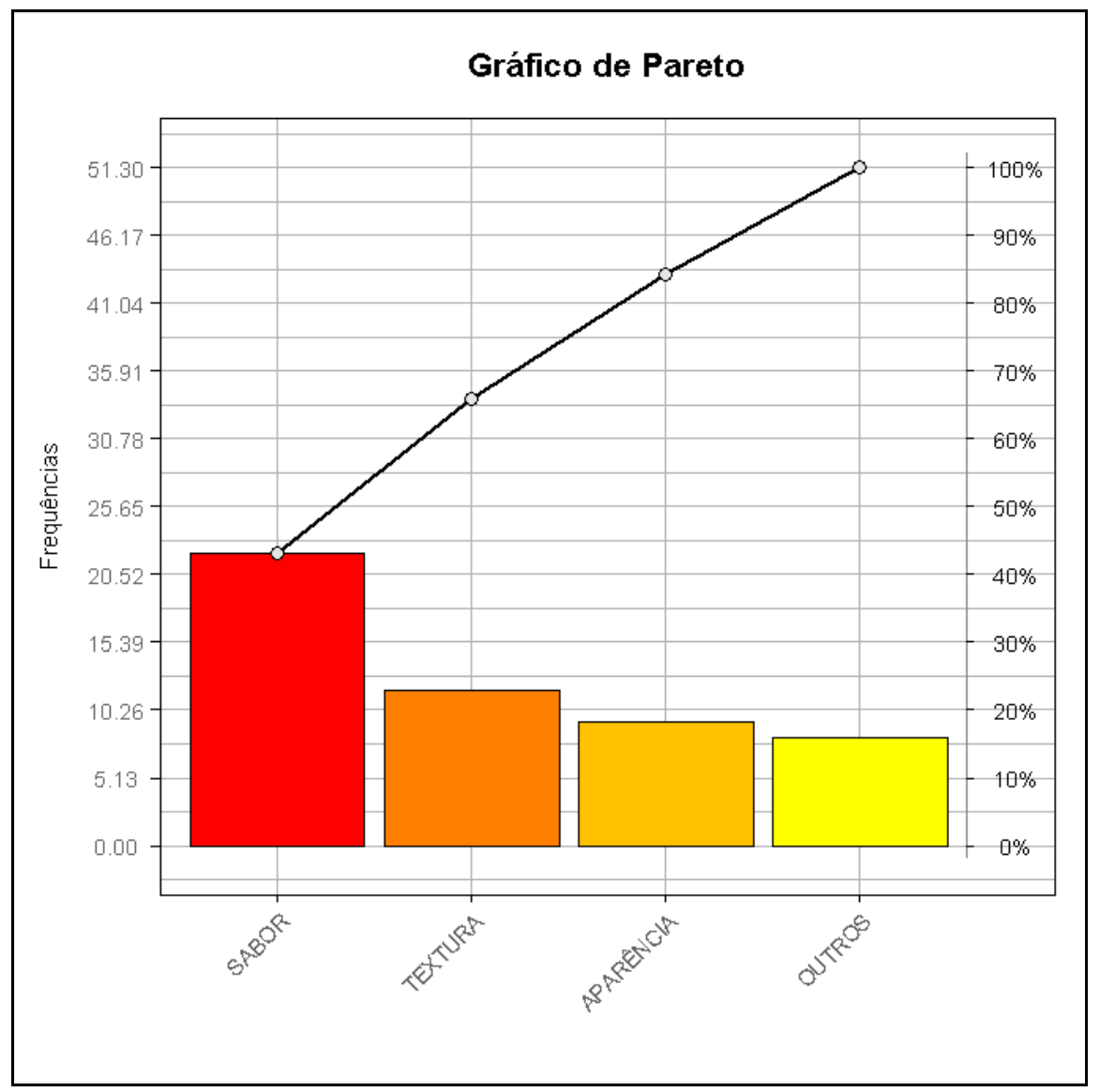

Fonte: Dados obtidos do SAC da empresa "A".

Tabela 4: Frequências relativas dos dados de reclamações obtidas pelo SAC no ano de 2018, relativas às características de sabor de margarinas

\begin{tabular}{lcccc}
\hline \multicolumn{5}{c}{ Frequências Relativas } \\
\hline \multicolumn{1}{c}{ Categorias } & Frequência & $\begin{array}{c}\text { Frequência } \\
\text { Acumulada }\end{array}$ & Porcentagem & $\begin{array}{c}\text { Porcentagem } \\
\text { Acumulada }\end{array}$ \\
\hline Sabor ranço & 7,57 & 7,58 & 34,32 & 34,32 \\
Sabor muito salgado & 4,99 & 12,55 & 22,55 & 56,86 \\
Sabor & 4,55 & 17,09 & 20,59 & 77,45 \\
Sabor diferente & 4,04 & 21,14 & 18,30 & 95,75 \\
Sabor com pouco sal & 0,94 & 22,08 & 4,25 & 100 \\
\hline
\end{tabular}


Figura 7: Gráfico de Pareto apresentando a classificação dos principais problemas relacionados ao sabor de margarinas produzidas pela empresa "A", das reclamações obtidas pelo SAC no ano de 2018.

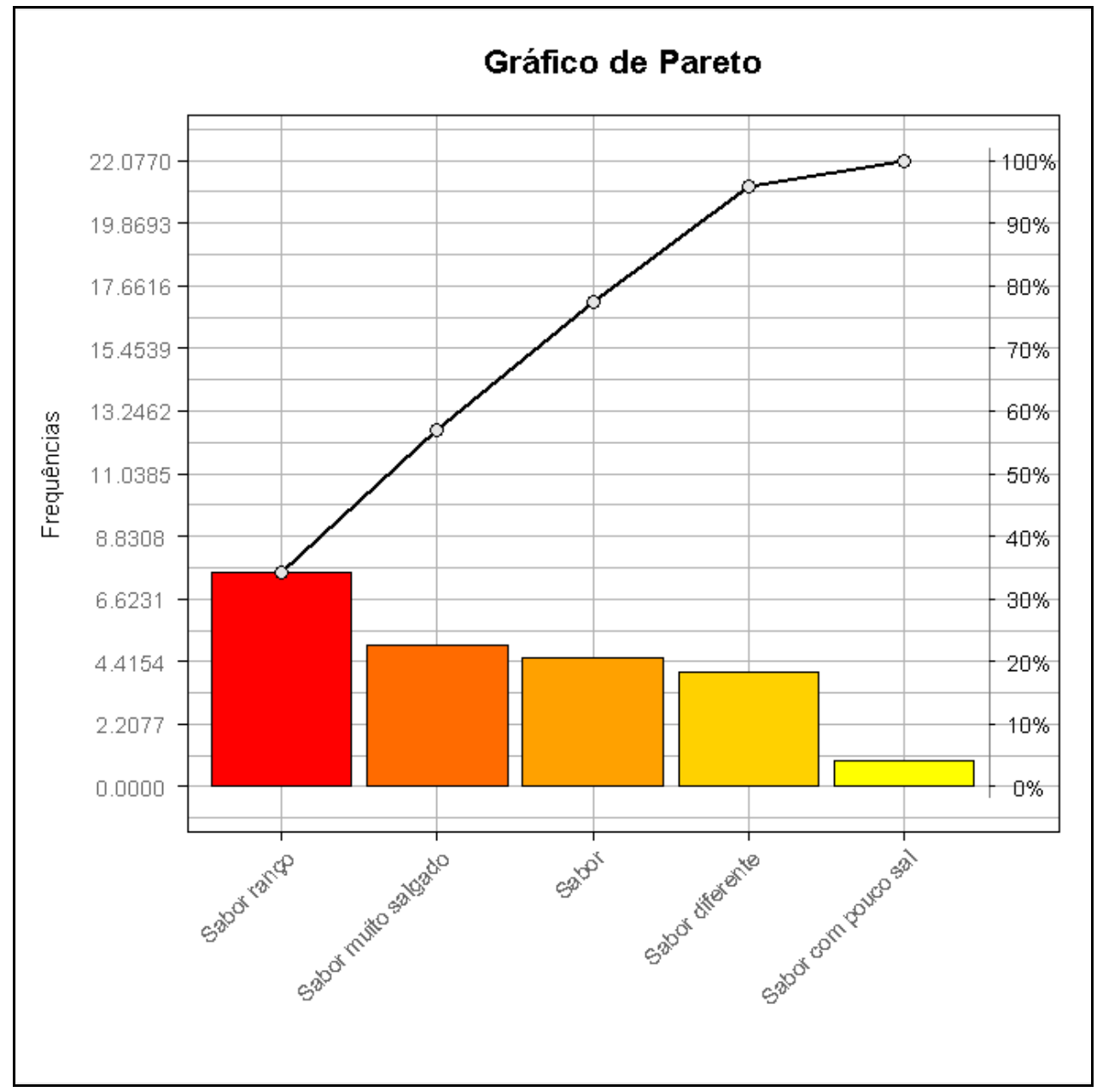

\subsection{Análise sensorial}

Os resultados apresentados evidenciam as duas condições de estocagem da margarina:

- Resultados da vida útil com as principais alterações nas características sensoriais na estocagem em temperatura controlada até 180 dias.

- Resultados das características sensoriais das margarinas encontradas nos pontos de vendas, comparativamente com o tempo 0. 


\subsubsection{Características sensoriais das margarinas obtidas de condições controladas de estocagem}

As margarinas de 4 diferentes lotes foram armazenadas em temperatura controlada e avaliadas nos pontos 2, 45, 90, 135, 180 dias, de acordo com os atributos previamente estabelecidos.

A Tabela 5 mostra de forma quantitativamente as alterações sensoriais em cada dos diferentes atributos de:

- Aparência: Cor amarela

- Sabor: Gosto salgado, sabor amanteigado, sabor ranço

- Textura: Cremosidade, derretimento na boca

Tabela 5: Resultados da avaliação das margarinas estocadas em condições controladas

\begin{tabular}{ccccccc}
\hline & $\begin{array}{c}\text { Cor } \\
\text { amarela }\end{array}$ & $\begin{array}{c}\text { Gosto } \\
\text { salgado }\end{array}$ & $\begin{array}{c}\text { Sabor } \\
\text { amanteigado }\end{array}$ & $\begin{array}{c}\text { Sabor } \\
\text { ranço }\end{array}$ & Cremosidade & $\begin{array}{c}\text { Derretimento } \\
\text { na boca }\end{array}$ \\
\hline $\begin{array}{c}\text { Controle }(2 \\
\text { dias })\end{array}$ & 2,0 & 5,0 & 4,0 & 0,0 & 5,0 & 4,0 \\
\hline 45 dias & 2,0 & 5,0 & 4,0 & 0,0 & 4,2 & 3,2 \\
\hline 90 dias & 2,0 & 5,0 & 3,2 & 0,0 & 4,0 & 3,0 \\
\hline 135 dias & 2,0 & 5,0 & 3,2 & 0,5 & 3,5 & 3,0 \\
\hline 180 dias & 2,2 & 5,0 & 2,75 & 1,0 & 3,2 & 2,2 \\
\hline
\end{tabular}

\subsubsection{Características sensoriais da aparência das margarinas obtidas de condições controladas de estocagem}

Nesta avaliação em condições estáveis não houve nenhuma variação na cor até 135 dias de estocagem, com 180 dias observou-se um ligeiro aumento na cor.

De acordo com Nawar (1985) a margarina pode apresentar descoloração da superfície durante o armazenamento, este resultado é 
diferente do encontrado neste estudo onde praticamente não ocorreu nenhuma alteração.

Nadeen et al. (2017) relataram que após 90 dias de vida útil em condições controladas de $5^{\circ} \mathrm{C}$, as margarinas (controle e testes com antioxidantes) não sofreram alterações na cor, resultados muito próximos aos apresentados neste estudo.

\subsubsection{Características sensoriais de sabor das margarinas obtidas de condições controladas de estocagem}

A Tabela 5 também evidência que o atributo gosto salgado não apresenta variações na estocagem com temperatura controlada. $O$ atributo manteve-se em intensidade moderada (5) do início (2 dias) ao fim do estudo (180 dias).

Não foram encontrados estudos que comparassem as alterações do atributo gosto salgado ao longo da estocagem.

De acordo com a Tabela 5 o atributo sabor amanteigado apresenta variações de intensidades ao longo da estocagem a $8^{\circ} \mathrm{C}$. Entre 2 a 45 dias de estocagem todas as amostras apresentavam moderada (4) intensidade do sabor amanteigado, que reduziu no decorrer da estocagem chegando até percepções próximas de leve a moderada (3) intensidade, com média final de 2,75. Nestas condições as principais alterações do atributo ocorrem entre 90 e 180 dias.

Zhang et al. (2006) não encontrou grandes alterações de sabor no em armazenamento a $5^{\circ} \mathrm{C}$ durante 12 semanas de estudo (90 dias), o que concorda com as alterações ocorridas neste estudo a $8^{\circ} \mathrm{C}$, onde observou-se muito leve perda de sabor amanteigado a partir de 90 dias e de estocagem.

Nadeem et al. (2017) concluiu que após 90 dias de armazenamento a $5^{\circ} \mathrm{C}$ da margarina controle e demais testes com utilização de chia para redução da oxidação, não apresentaram alterações nas características sensoriais de sabor no período.

A Tabela 5 evidencia que a margarina armazenada em condições controladas está mais suscetível ao aparecimento do sabor ranço entre os dias 
de estocagem 135 e 180 dias, vale ressaltar que esta característica é ausente no início do armazenamento. Durante toda estocagem sob condições controladas o sabor ranço foi observado no ponto 135 dias em intensidade próximas a ausente (0) e com 180 e intensidades próximas a (1) muito leve intensidade. A oxidação lipídica ocorre durante seu armazenamento podendo ocasionar o sabor ranço. Nadeem et al. (2017) conseguiram minimizar os efeitos da estocagem na margarina com a inclusão do óleo de chia no produto, o ingrediente agiu como antioxidante natural. A margarina avaliada neste estudo também apresenta inclusão de antioxidantes, o que justifica a estabilidade oxidativa nestas condições.

\subsubsection{Características sensoriais de textura das margarinas obtidas de condições controladas de estocagem}

No primeiro ponto de avaliação, 2 dias, a margarina apresentava moderada a forte (5) cremosidade, que foi reduzindo ao longo dos pontos de estocagem 45, 90, 135 e; com 180 dias apresentavam na sua maioria uma média de próxima de leve a moderada (3) cremosidade, como mostrado na Tabela 5.

Em estudo de estabilidade de margarinas com gorduras interesterificadas nas temperaturas de $5^{\circ} \mathrm{C}$ e, $25^{\circ} \mathrm{C}$, Zhang, Jacobesen e AdlerNisser (2005), através de resultados analíticos de consistência concordam que a dureza da margarina aumenta mesmo quando mantidas armazenadas apenas em geladeira.

Kotera (2017) em estudo comparativo da dureza sensorial de manteigas e margarinas concluiu que estes produtos tendem ser mais duros/ firmes mesmo quando armazenados continuamente a $5^{\circ} \mathrm{C}$ temperatura. Os resultados deste estudo também demonstraram que mesmo em condições laboratoriais as margarinas ficam menos cremosas ou mais firmes analiticamente

$\mathrm{Na}$ avaliação do derretimento na boca observa-se variação entre os dados, no início a margarina apresentava moderado (4) derretimento na boca, entretanto no final da vida útil a maioria dos produtos apresentavam leve (1) derretimento na boca. Ocorreram transformações no atributo derretimento 
na boca entre os pontos 45 dias e 180 dias. Os resultados são apresentados na Tabela 5.

Durante o derretimento da margarina de mesa é possível perceber através das papilas gustativas os aromas e sabores sem que apareça uma sensação de desagradável de "sebo" na boca. O percentual de gordura sólida afeta a qualidade da margarina de mesa, que está relacionado com o derretimento do produto. De acordo com Chrysan (2005) é possível afirmar que uma margarina tem um bom derretimento quando se funde completamente na temperatura de $36^{\circ} \mathrm{C}$. Os dados demonstram a tendência de redução do derretimento na boca ao longo da estocagem ou seja, a fusão da margarina torna-se mais lenta.

De um modo geral a Tabela 5 demonstra as alterações sensoriais ao longo da estocagem controlada, evidenciando que as principais alterações são a redução da cremosidade, do derretimento na boca e do sabor amanteigado

Há variações nas características sensoriais no início (2 dias), meio (90 dias) e fim (180 dias) da estocagem, onde observa-se principalmente redução do derretimento na boca e da cremosidade.

\subsection{Avaliação da vida útil das margarinas nos pontos de vendas}

\subsubsection{Temperatura das margarinas obtidas no ponto de venda}

A Tabela 6 mostra as temperaturas das margarinas no momento da compra nos pontos de vendas, onde foram observadas temperaturas variando de $1^{\circ} \mathrm{C}$ até $9^{\circ} \mathrm{C}$. 
Tabela 6: Temperaturas das margarinas nos pontos de venda

\begin{tabular}{ccccc}
\hline $\begin{array}{c}\text { Local de } \\
\text { compra }\end{array}$ & $\begin{array}{c}\text { Média } \\
\text { Temperatura }\end{array}$ & $\begin{array}{c}\text { Temperatura Temperatura } \\
\text { Mínima }\end{array}$ & Máxima & Desvio \\
\hline São Paulo & 6,0 & 2,0 & 9,0 & 7,0 \\
Belo Horizonte & 5,7 & 5,0 & 6,2 & 4,2 \\
Campinas & 5,6 & 1,2 & 8,1 & 6,1 \\
Rio de Janeiro & 5,5 & 1,0 & 8,0 & 6,0 \\
Curitiba & 5,6 & 4,0 & 6,9 & 4,9 \\
Cuiabá & 7,0 & 7,0 & 7,0 & 5,0 \\
Salvador & 6,3 & 5,0 & 8,0 & 6,0 \\
\hline
\end{tabular}

A Portaria no 372 de 04/09/1997 (BRASIL, 1997) determina que a margarina seja conservada e comercializada em temperatura não superior a $16^{\circ}$, portanto apesar da alta variação nas condições de estocagem, todas estão de acordo com a legislação.

Apesar desta variação de temperatura estar de acordo com a legislação foi relatado por Tanaka et al (2007) que variações na temperatura na estocagem proporcionam formação de cristais granulares, que reduzem a qualidade do produto à base de óleo de palma e esta formação é acelerada por ciclos térmicos de 7 a $15^{\circ} \mathrm{C}$.

Quando a margarina é deixada fora da geladeira, mesmo que por um período, isso pode levar a recristalização de glicerídeos de fusão mais elevada e a um aumento do ponto de fusão, estas alterações impactam nas características sensoriais dos produtos, resultando em uma sensação mais pesada na boca e na liberação de sabor e sal mais lenta (CHRYSAN, 2005).

De acordo com Kotera et al. (2017) produtos à base de gordura semi-sólida como as margarinas são sensíveis a choques térmicos, mesmo entre refrigeração e condições de ambiente. Estas variações na temperatura podem resultar na deterioração da qualidade do produto, porque geram cristais granulares e causam endurecimento do produto.

É indispensável um olhar atento para a forma de armazenamento nos pontos de vendas já que a variação de temperatura pode impactar negativamente na qualidade do produto final. 


\subsubsection{Tempo de vida útil das margarinas dos pontos de venda}

Todas as amostras controle foram avaliadas com 2 dias de vida útil, já as margarinas dos pontos de vendas apresentaram estocagem variando de 26 a 171 dias, informações evidenciadas na Figura 8.

A margarina possui vida útil de 180 dias (6 meses), porém mais de $80 \%$ dos produtos encontrados nos pontos de venda e avaliados na metodologia de perfil de consenso encontravam-se entre 30 e 90 dias (1 a 3 meses), isto pode ser justificado pela alta rotatividade do produto que não permite encontrar grandes quantidades de produto com tempo de estocagem mais avançados, conforme mostra a Figura 8.

Figura 8: Tempo de vida útil das margarinas avaliadas sensorialmente

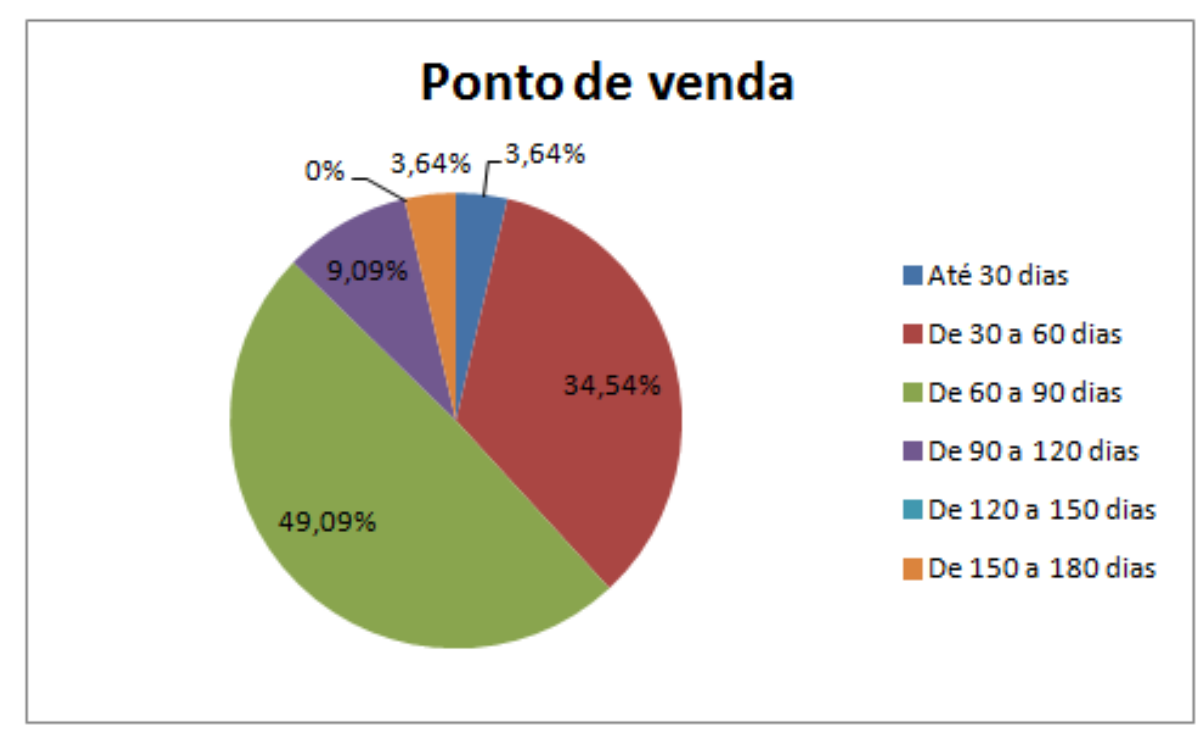

\subsection{Características sensoriais das margarinas obtidas no ponto de venda}

A Tabela 7 apresenta a análise estatística de cada atributo (cor amarela, gosto salgado, sabor amanteigado, sabor ranço, cremosidade e derretimento na boca) de amostras coletadas em pontos de venda comparativamente com as amostras controle (2 dias de estocagem). 
Tabela 7: Média e a diferença mínima significativa (DMS) dos atributos sensoriais

\begin{tabular}{|c|c|c|c|c|c|c|}
\hline & $\begin{array}{c}\text { Cor } \\
\text { amarela }\end{array}$ & $\begin{array}{l}\text { Gosto } \\
\text { salgado }\end{array}$ & $\begin{array}{c}\text { Sabor } \\
\text { amanteigado }\end{array}$ & $\begin{array}{l}\text { Sabor } \\
\text { ranço }\end{array}$ & Cremosidade & $\begin{array}{c}\text { Derretimento } \\
\text { na boca }\end{array}$ \\
\hline Controle & $1,71^{a}$ & $4,90^{\mathbf{a}}$ & $3,92^{\mathbf{a}}$ & $0,00^{\mathbf{a}}$ & $4,82^{a}$ & $3,92^{\mathbf{a}}$ \\
\hline $\begin{array}{l}\text { Ponto de } \\
\text { venda }\end{array}$ & $1,86^{\mathbf{b}}$ & $4,83^{a}$ & $3,67^{\mathbf{b}}$ & $0,29^{b}$ & $4,02^{\mathbf{b}}$ & $2,30^{\mathbf{b}}$ \\
\hline DMS & 0,15 & 1,98 & 0,14 & 0,21 & 0,32 & 0,27 \\
\hline
\end{tabular}

Letras iguais na mesma coluna não apresentam diferença significativa ao nível de 95\% de confiança

Os resultados da Tabela 7 mostram que existe diferença significativa na comparação das margarinas "controle" com o "ponto de venda" na maioria dos atributos avaliados: cor amarela, sabor amanteigado, sabor ranço, cremosidade e derretimento na boca vale ressaltar que não há alteração significativa na característica de gosto salgado. Estas importantes alterações nas características dos produtos estocados nos pontos de vendas podem justificar algumas reclamações dos consumidores

$\mathrm{Na}$ condição de estocagem no ponto de venda observou-se que as margarinas têm uma tendência de aumentar a cor amarela, reduzir o sabor amanteigado, reduzir a cremosidade, reduzir o derretimento na boca, além de estarem mais suscetíveis ao surgimento do sabor ranço.

\subsubsection{Características sensoriais da aparência das margarinas obtidas nos pontos de vendas}

$\mathrm{Na}$ condição real de estocagem as margarinas apresentaram aumento da cor amarela, com notas próximas a (2), sendo leve a intensidade de cor amarela no final da estocagem.

Nenhum estudo relatou as alterações sensoriais na cor da margarina em condições reais de estocagem. 


\subsubsection{Características sensoriais de sabor e textura das margarinas obtidas nos pontos de vendas}

A Tabela 7 evidencia que 0 atributo gosto salgado não apresenta variações na estocagem em condições reais. Do início ao fim da do armazenamento o atributo é observado com notas médias próximas de moderado a forte (5) intensidade. Já o atributo sabor amanteigado apresenta redução de intensidades, chegando até percepções próximas de leve a moderada (3) intensidade, com média final de 3,67. Lembrando que mais de $80 \%$ das amostras apresentavam vida útil de até 90 dias.

A Tabela 7 também mostra o sabor ranço aumentou ao longo da estocagem, ou seja, a margarina armazenada em condições reais está mais suscetível ao aparecimento do sabor ranço no período de até 90 dias, vale ressaltar que esta característica é ausente no início do armazenamento.

No primeiro ponto de avaliação, 2 dias, a margarina apresentava moderada a forte (5) cremosidade, média de 4,82, que foi reduzindo ao longo da estocagem chegando até média próxima de leve a moderada (4) cremosidade, como mostrado na Tabela 7.

$\mathrm{Na}$ avaliação do derretimento na boca observa-se redução desta característica durante a estocagem de moderado derretimento na boca, média 3,92, para leve (2) média de 2,30. Os resultados são apresentados na Tabela 7.

Alguns autores trazem os resultados de sabor correlacionados com a textura, como Shiota et al. (2011) que em estudo do comportamento das substâncias aromáticas em emulsões A/O relatou através de dados sensoriais que o ponto de fusão (tempo de derretimento na boca) gera interferência na percepção do sabor, pois quando a gordura funde mais lentamente também ocorre uma liberação de sabor mais lenta na boca. Ele concluiu que a liberação do aroma base óleo de uma emulsão é influenciada pela interação entre os compostos voláteis e os compostos dispersos. Este resultado vem de encontro com os dados deste estudo, onde houve a redução do derretimento na boca, ou seja, a margarina está com um ponto de fusão mais alto, e isto provavelmente está impactando na redução do sabor amanteigado. Da mesma 
forma foi demonstrado por Vaisey-Genser (2003) que também menciona que o rápido derretimento de margarinas na boca tem correlação com a liberação imediata de sabores.

Cheong et al (2009) comprovaram por métodos analíticos, que após 3 meses de estocagem ocorre um aumento do ponto de derretimento de $2,5^{\circ} \mathrm{C}$ das margarinas comerciais, além de um aumento significativo da firmeza. Estas alterações estão relacionadas com as transformações polimórficas, de $\beta$ para $\beta$ ', que segundo os autores se iniciam após 8 semanas de estocagem em margarinas comerciais.

Segura; Herrera; Añón (1995) demonstraram que margarinas comerciais estocadas em temperaturas distintas $4^{\circ} \mathrm{C}$ e $13^{\circ} \mathrm{C}$, tornam-se mais firmes, respectivamente, em medições analíticas realizadas na temperatura de $15^{\circ} \mathrm{C}$. Neste estudo, sem temperatura controlada, observou-se uma tendência de as amostras ficarem menos cremosas e/ou mais firmes.

\subsection{Comparativo das características sensoriais nas condições de estocagem}

Como os resultados de tempo de vida útil indicaram que $80 \%$ das margarinas encontradas no ponto de venda estavam com tempo de estocagem menor ou igual a 90 dias, foi realizado um comparativo destes atributos sensoriais com os atributos das margarinas com até 90 dias de vida útil em condições controlada, demonstrado na Figura 9. 
Figura 9: Comparativo das características sensoriais

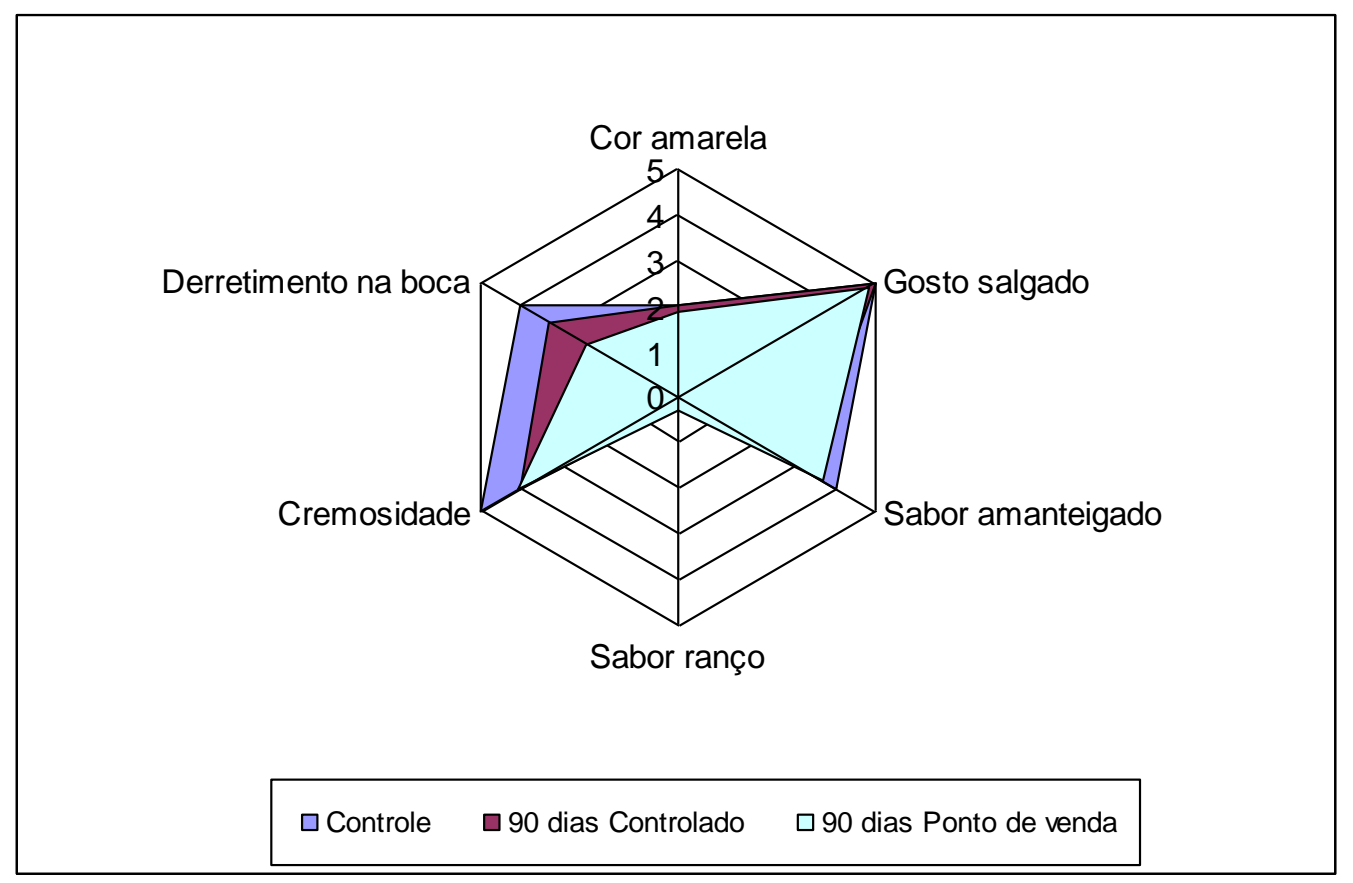

De forma qualitativa os dados evidenciam que em um mesmo período as margarinas armazenadas nos pontos de vendas apresentam uma maior variação nos atributos sensoriais. Na estocagem controlada observou-se apenas variação em um único atributo, derretimento na boca, enquanto no mesmo período as características das margarinas pontos de vendas também apresentaram redução da cremosidade, em maiores intensidades que condições controladas, além da redução do derretimento na boca da intensidade de sabor amanteigado.

De acordo com Silva et al. (2008) na etapa de cristalização do processo produtivo da margarina ocorrem a formação de gorduras na forma $\beta$ ', devido ao rápido resfriamento e plastificação. As condições de armazenamento, o comportamento de cristalização das gorduras, a transição do cristal da forma $\beta$ ' para a forma $\beta$ ocorre de forma mais lenta ou rápida, podendo levar a alterações nas características reológicas da margarina com a piora do derretimento, aparecimento da arenosidade, perda da cremosidade e até quebra da emulsão. Neste estudo o armazenamento a condição real de estocagem favoreceu a perda da cremosidade e o aumento do tempo de derretimento na boca. Não foram verificadas alterações na aparência arenosa e 
quebra na emulsão. Estas alterações podem ser embasadas pelo estudo de estabilidade de margarinas conduzidas por Zhang, Jacobsen e Adler-Nissen (2005) onde confirmaram que ocorrem transformações polimórficas de $50 \%$ dos cristais, da forma $\beta^{\prime}$ para a forma $\beta$ em um período de 12 semanas (90 dias), sendo que inicialmente eram $100 \%$ da forma $\beta$ '.

Ares e Varela (2017) indicaram que resultados encontrados com equipes de consumidores não treinados, são muito próximos aos avaliadores treinados, portanto é possível fazer o comparativo dos resultados obtidos deste estudo com as reclamações dos consumidores.

- Na aparência os consumidores reclamaram principalmente da cor amarela, sem mencionar características de intensidade, nesse estudo não se observou variações neste atributo.

- No sabor as reclamações estão mais voltadas para ranço, sabor e sabor muito salgado. As avaliações das margarinas dos pontos de vendas indicam uma redução do sabor amanteigado ao longo da estocagem, o que por si só pode gerar reclamação, além desta redução facilitar a percepção de características desagradáveis como sabor ranço. Neste estudo não foram relatadas variações no atributo gosto salgado que pudessem justificar as reclamações de muito gosto salgado, entretanto as reclamações podem estar relacionadas com a percepção individual de cada consumidor.

- Na textura as reclamações de consistência/textura possivelmente estão relacionadas com a perda de cremosidade detectada no produto armazenado no ponto de venda. Não houve variações na textura que justificassem as reclamações de textura líquida e textura mole, imagina-se que esta alteração esteja relacionada com a temperaturas de estocagem acima do praticado neste estudo. 


\section{CONCLUSÃO}

A conclusão está baseada em amostras com o mesmo tempo de estocagem (90 dias). Observa-se que em condições controladas de armazenamento quase não há variações nos atributos de aparência e sabor, porém foram encontradas alterações na textura devido a redução do derretimento na boca.

$\mathrm{O}$ armazenamento das margarinas nos pontos de venda deixa a margarina mais susceptível as alterações nas características sensoriais principalmente na textura, onde se observa uma redução ainda maior do derretimento da boca, o que começa a impactar a percepção de sabor devido a redução do amanteigado.

Os resultados apresentados sugerem que algumas reclamações dos consumidores podem estar relacionadas com a estocagem nos pontos de vendas;

Para mitigar os efeitos da estocagem é indispensável que a distribuição e o armazenamento da margarina durante sua vida útil, sejam feitos de maneira adequada, ou seja, sem que haja oscilações de temperatura. Desta forma pode-se evitar a perda da qualidade da margarina e possíveis reclamações dos consumidores. 


\section{REFERÊNCIAS}

1. ABNT- Associação Brasileira de Normas Técnicas. NBR ISO 13299:2017 - Análise sensorial: Metodologia: Orientação geral para estabelecimento de perfil sensorial. Rio de Janeiro, ABNT, 2017.

2. ABNT- Associação Brasileira de Normas Técnicas. NBR ISO 8586:2012 - Análise sensorial: Metodologia: Guia geral para seleção, treinamento e monitoramento de avaliadores selecionados e de especialistas ou experts. Rio de Janeiro, ABNT, 2012.

3. ABNT- Associação Brasileira de Normas Técnicas. NBR ISO 5492:2008 - Análise sensorial: Vocabulário, ABNT, 2008.

4. AINI, I.N; MISKANDAR, M.S. Utilization of palm oil products in shortening and margarines. European Jornal of Lipid and Technology. Hoboden, v. 109, n.4, p-422-432, 2007.

5. ALEXANDERSEN, K. A. Margarine processing plants and equipment. Edible Oil \& Fat Products: Processing Technologies. Bailey's industrial oil and fat products, Wiley online library, 2005.

6. AMERICAN SOCIETY FOR TESTING AND MATERIALS. Guideline for the selection and training of sensory panels members - STP 758, Philadelphia: ASTM, 1981.

7. ANDRADE, P. H. S. et al. O impacto do Programa 5 S na implantação e manutenção de sistemas da qualidade. Dissertação (mestrado) Universidade Federal de Santa Catarina, Centro Tecnológico. Programa de Pós-Graduação em Engenharia de Produção, 2002.

8. ANDREO, D. et al. Antioxidantes naturais: Técnicas de Extração.

Boletim do Centro de Pesquisas de Processamento de Alimentos. Curitiba, v. 24, n. 2, 319-336, 2006.

9. ANZALDÚA-MORALES, A. La evaluación sensorial de los alimentos en la teoría y la prática. Zaragoza: Acribia SA, 1994. 198p. 
10. ARES, G; VARELA, P. Trained vs. consumer panels for analytical testing: Fueling a long lasting debate in the field. Food Quality and Preference, v. 61 , p. $79-86,2017$

11. AVELINO, A. C.; SALVAGNI, R. B. Qualidade no processo de produção - um modelo de gestão para garantir a qualidade de acabamento das carrocerias em chapa na linha de produção. 2005. Universidade de São Paulo, São Paulo, 2005.

12. BASTOS, E. F. S. da et al. Propriedades reológicas e de estabilização de emulsões do FucoPol. 2013. Tese de Doutorado. ISA.

13. BECKER-ALMEIDA, D. F. S. et al. Desenvolvimento e aplicação de gorduras low trans em margarina e bolo tipo inglês. 200 BERNARDINO, E. C. et. al. Marketing de varejo. Rio de Janeiro: FGV, 2004.

14. BERTOLINO, M. T. Gerenciamento da qualidade na indústria alimentícia: ênfase na segurança dos alimentos. Porto Alegre 2010.

15. BHATNAGAR, A. S. et al. Fatty acid composition, oxidative stability, and radical scavenging activity of vegetable oil blends with coconut oil. Journal of the American Oil Chemists' Society, v. 86, n. 10, p. 991-999, 2009

16. BITNER, M. J.; BOOMS, B. H.; TETREAULT, M. S. The service encounter: diagnosing favorable and unfavorable incidents. Journal of marketing, $\mathrm{v}$. 54, n. 1, p. 71-84, 1990.

17. BOCKISCH, M. (Ed.). Fats and oils handbook (Nahrungsfette und Öle). Elsevier, 2015.

18. BRASIL. Ministério da Agricultura, Pecuária e Abastecimento. Portaria $n^{\circ}$ 372, de 4 de setembro de 1997. Regulamento técnico para fixação de identidade e qualidade da margarina. Diário Oficial da União, 1997.

19. CERIBELI, H. B. Experiências de consumo e satisfação dos clientes no setor supermercadista: um estudo no interior do Estado de São Paulo. Tese de Doutorado. Universidade de São Paulo, 2011.

20. CHAMBERS IV, E.; BOWERS, J. A.; DAYTON, A. D. Statistical designs and panel training/experience for sensory analysis. Journal of Food Science, v. 46, n. 6, p. 1902-1906, 1981. 
21. CHARTERIS, W. P. Microbiological quality assurance of edible table spreads in new product development. International Journal of Dairy Technology, v. 49, n. 3, p. 87-98, 1996.

22. CHAVES, J. B. P. Avaliação sensorial de alimentos (Métodos de Análises). Viçosa. Editora da Universidade Federal de Viçosa, 1980.

23. CHEONG, L.; TAN, C.; LONG, K.; SURIA AFFANDI YUSOFF, M.; LAI, O. Physicochemical, Textural and Viscoelastic Properties of Palm Diacylglycerol Bakery Margarine During Storage. Journal of American Oil Chemical Society, v. 86, p. 723-731, 2009.

24. CLEMENTE, E. S. A garantia da segurança dos alimentos perecíveis no setor supermercadista. 2003. 279f. 2003. Tese de Doutorado. Tese (Doutorado em Engenharia de Alimentos) -Universidade Estadual de Campinas, Campinas.

25. COBRA, M. Administração de marketing no Brasil. Elsevier Brasil, 2009

26. CORREIA, A. F. K. Implementação de um sistema de qualidade para laboratório de análise sensorial baseado no sistema de boas práticas. Dissertação de Mestrado Ciência e Tecnologia de Alimentos. Universidade de São Paulo, 2005.

27. CHRYSAN, M. M. Margarines and spreads. Bailey's industrial oil and fat products, 2005.

28. DATORRE, C. C. J.; HERMOSILLA, J. L.; SILVA, E. C. C. Aplicação do Método Quality Function Development/QFD no Desenvolvimento de Produto em uma Empresa Fabricante de Implementos Agrícolas. FTT Journal of Engineering and Business, v. 1, n. 1, 2016

29. DELAMARRE, S.; BATT, C. A. The microbiology and historical safety of margarine. Food Microbiology, v. 16, n. 4, p. 327-333, 1999.

30. DEMAN, J. M.; DEMAN, L.; BLACKMAN, B. Melting-point determination of fat products. Journal of the American Oil Chemists' Society, v. 60, n. 1, p. $91-94,1983$

31. DO CONSUMIDOR, Código de Defesa. Lei o 8.078 de 11 de Setembro de 1990. Art. 14º, $4^{\circ} \div 2013$. 
32. DUTCOSKY, S. D.i. Análise sensorial de alimentos. In: Análise sensorial de alimentos. Editora Universitária Champagnat, 2013.

33. FREEMAN, I. P.; MELNIKOV, S. M. Margarines. In Ullmann's encyclopedia of industrial chemistry. p. 1-24. Wiley-VCH Verlag GmbH \& Co. KGaA. 2015.

34. GARTI, N.; SATO, K. Crystallization processes in fats and lipid systems. Marcel Dekker. p. 211-250, 2001.

35. GOLD, I. L.; IKHUN, M.E.; AKOH, C.C. Characteristics of eutectic compositions of restructured palm oil oleina, palm kernel oil and their mixtures. Jornal of American Oil Chemistry's Society. Champaign, v. 88, n. 11, p. 1659-1667, 2011.

36. GUNSTONE, F. D. (2006). Modifying Lipids for Use in Food (p. 608). Woodhead Publishing Limited.

37. HEERTJE, I.; VAN EENDENBURG, J.; CORNELISSEN, J. M.; JURIAANSE, A. C. Food Microstruct., v.7, n.189, 1988.

38. HOLLIDAY, S. L.; ADLER, B. B.; BEUCHAT, Larry R. Viability of Salmonella, Escherichia coli O157: H7, and Listeria monocytogenes in butter, yellow fat spreads, and margarine as affected by temperature and physical abuse. Food microbiology, v. 20, n. 2, p. 159-168, 2003.

39. IBARZ, A.; RIBAS, A. Iz. Operaciones unitarias en la ingeniería de alimentos. Mundi-Prensa Libros, 2005.

40. ISHIKAWA, K. Controle de qualidade total à maneira japonesa. In: Controle de qualidade total à maneira japonesa. 1993.

41. KANTAR WORLDPANEL. Penetração de spreads no Brasil /Frequência de consumo de spreads. 2015. Disponível em: http://www.kantarworldpanel.com/global/. Acesso em: 10/06/2017

42. KELLENS, M. et al. Palm oil fractionation. European Journal of Lipid Science and Technology, v. 109, n. 4, p. 336-349, 2007.

43. KIM, B. H.; LUMOR, S. E.; AKOH, C. C. Trans-free margarines prepared with canola oil/palm stearin/palm kernel oil-based structured lipids. Journal of agricultural and food chemistry, v. 56, n. 17, p. 8195-8205, 2008. 
44. KINDERLERER, J. L. Degradation of the lauric acid oils. International biodeterioration \& biodegradation, v. 33, n. 4, p. 345-354, 1994.

45. KOTERA, M. et al. Effect of temperature conditions of the home environment on the physical properties of semi-solid fat products. Journal of Food Measurement and Characterization, v. 11, n. 1, p. 134-143, 2017.

46. KOTLER, P. Administração de marketing. 12 ed. São Paulo: Prentice Hall, 2010.

47. KOTLER, P.; KARTAJAYA, H.; SETIAWAN, I. Marketing 4.0: Moving from traditional to digital. John Wiley \& Sons, 2016.

48. LANNES, S. C.; IGNÁCIO, R. M. Structuring fat foods. In: Food industry. IntechOpen, 2013.

49. LAWLESS, H. T.; HEYMANN, H.. Sensory evaluation of food: principles and practices. Springer Science \& Business Media, 2013.

50. LIU, Y. et al. Influence of lipid composition, crystallization behavior and microstructure on hardness of palm oil-based margarines. European food research and technology, v. 230, n. 5, p. 759-767, 2010.

51. MACFARLANE, Neil. Methods of protection of products of increasing quality and value. Structured and Modified Lipids. Ed. FD Gunstone. Marcel Dekker, New York (USA), p. 37-74, 2001.

52. McClements, J. M. Crystals and crystallization in oil-in-water emulsions: Implications for emulsion-based delivery systems. Advances in Colloid and Interface Science, 174:1-30, 2012

53. MAGALHÃES, F. A. R. Métodos descritivos e avaliação sensorial de doce de leite pastoso. UFV, 1996.

54. MARANGONI, A. G. Fat crystal networks. CRC Press, 2005.

55. MARANGONI, A. G., \& WESDORP, L. H. (2013). Crystallography and Polymorphism. In Structure and Properties of Fat Crystal Networks (pp. $1-24)$. 
56. MATTILA, A. S.; WIRTZ, J. Consumer complaining to firms: the determinants of channel choice. Journal of Services Marketing, v. 18, n. 2, p. 147-155, 2004.

57. MENDES, M. F. R. O impacto dos sistemas QAS nas PME portuguesas. Tese de Doutorado, 2007.

58. MENDONÇA, R. O. Instituto Nacional de Metrologia, Normalização e Qualidade Industrial. Rev Meio Ambient Ind, v. 15, n. 1, p. 1-10, 2006

59. METIN, S.; HARTEL, R. W. Cristalization of fat and oils. In: SHAHIDI, F. Bailey's Industrial Oil and Fat Products. 6 ed., John Wiley \& Sons, v.1, p. 45-76, 2005.

60. MINIM, V. P. R. Análise sensorial: estudos com consumidores. Universidade Federal de Viçosa, 2006.

61. NADEEM, M. et al. Omega-3 fatty acids, phenolic compounds and antioxidant characteristics of chia oil supplemented margarine. Lipids in health and disease, v. 16, n. 1, p. 102, 2017.

62. NARINE, S. S.; MARANGONI, A. G. Fractal nature of fat crystal networks. Physical Review E, v. 59, n. 2, p. 1908, 1999.

63. Nawar WW. Lipids. In: Nawar WW (ed) Food chemistry, 2nd edn. Marcel Dekker Inc, New York, pp 139-245, 1985.

64. O'BRIEN, R. D. Fat and oils: formulating and processing for applications. 3. ed. Boca Raton: Crc Press, 2009. $766 \mathrm{p}$

65. OLIVER, W. R.; MAcGill, D.C. Buter and margarine: Their chemistry, their conflict. Journal of Chemistry Education. Washington, v. 64, n.7, p. 596598, 1987.

66. OLIVEIRA, G. M. et al. Obtenção e caracterização de bases lipídicas destinadas à estabilização do polimorfismo de lipídios com ênfase na manteiga de cacau. Tese de Doutorado Faculdade de Engenharia Química -Universidade Estadual de Campinas, Campinas, 2016

67. PARENTE, J. Varejo no Brasil: gestão e estratégia. Editora Atlas, 2000. 
68. PEDERSEN, A.; P., A. La fabricación de margarina. Tecnología y proceso. Alimentación, Equipos y Tecnología. 1994.

69. PERIN, R. Implementação de um sistema de controle distribuído em uma linha de produção de margarina. Florianópolis, 2018.

70. PISKA, Ivo et al. Properties and crystallization of fat blends. Journal of Food Engineering, v. 77, n. 3, p. 433-438, 2006.

71. RANJITH, H. M. P. Water continuous emulsions, In RAJAH, K.K. Ed. Fats in food technology. Sheffield Academic Press: CRC Press. 2002, p. 69122.

72. Richins, M.L. Negative Word-of-mouth by Dessatisfied Consumers: A Pilot Study. Journal of Marketing, vol. 47, winter 1983. (pp. 68-78).

73. ROBINSON, David S.; ESKIN, Michael. Food shelf life stability: chemical, biochemical, and microbiological changes. CRC Press, 2000.

74. ROUSSEAU, Dérick et al. Restructing butterfat through blending and chemical interesterification. 1. Melting behavior and triacylglycerol modifications. Journal of the American Oil Chemists' Society, v. 73, n. 8 , p. 963-972, 1996.

75. SANTOS, C. P.; ROSSI, C A. O impacto do gerenciamento de reclamações na confiança e na lealdade do consumidor. Revista de Administração Contemporânea, v. 6, n. 2, p. 49-73, 2002

76. SATO, K. Crystallization behavior of fats and lipids: a review. Chemical Engineering Science. v. 56, n. 7, p. 2255-2265, 2001.

77. SEGURA, J. A.; HERRERA, M. L.; ANON, M. C. Margarines: a rheological study. Journal of the American Oil Chemists' Society, v. 72, n. 3, p. 375378, 1995.

78. SHIOTA, M. et al. Model studies on volatile release from different semisolid fat blends correlated with changes in sensory perception. Journal of agricultural and food chemistry, v. 59, n. 9, p. 4904-4912, 2011.

79. SILVA, J. R. Avaliação da estabilidade da margarina de mesa armazenada a temperatura de $30^{\circ} \mathrm{C}$, São Caetano do Sul, $94 \mathrm{p}$. 
Dissertação (Mestrado) - Faculdade de Engenharia de Processos Químicos e Bioquímicos, 2009.

80. SILVA, R. C.; ESCOBEDO, J. P.; GIOIELLI, L. A. Comportamento de cristalização de lipídios estruturados por interesterificação química de banha e óleo de soja. Química Nova, v. 31, n. 2, p. 330-335, 2008.

81. SINGH, J.; SIRDESHMUKH, D.. Agency and trust mechanisms in consumer satisfaction and loyalty judgments. Journal of the Academy of marketing Science, v. 28, n. 1, p. 150-167, 2000.

82. SOARES, F. A. S. M.i et al. Effects of chemical interesterification on physicochemical properties of blends of palm stearin and palm olein. Food research international, v. 42, n. 9, p. 1287-1294, 2009.

83. SOUTHWEEL. K; HARRIS, R; SWETMAN,T: Métodos analíticos modernos pra la medicion de la estabilidad y calidad de los aceites e las grasas. Aceites y grasas, Chacuco, v25, n.4, p. 547 a 552, dez;1996.

84. SPX $®$ Corporation. Margarine Production - Technology and Process. Charlotte, North Carolina, jul. 2012

85. STONE, H.; SIDEL, J. L. Quantitative descriptive analysis (The QDA Method), sensory evaluation practices. 2004.

86. TANAKA, L., MIURA, S. and YOSHIKA, T. (2007), Formation of Granular Crystals in Margarine with Excess Amount of Palm Oil. Journal of the American Oil Chemists' Society, 84: 421-426.

87. TANG, Dongming; MARANGONI, Alejandro G. Modeling the rheological properties and structure of colloidal fat crystal networks. Trends in food science \& technology, v. 18, n. 9, p. 474-483, 2007.

88. TEIXEIRA, E.; MEINERT, E. M.; BARBETTA, Pedro. Análise sensorial de alimentos. Ed. UFSC, 1987.

89. TIMMS, R. E. Phase behaviour of fats and their mixtures. Progress in Lipid Research, v. 23, n. 1, p. 1-38, 1984..

90. TIMMS, R. E. Crystallisation of fats. In: Developments in oils and fats. Springer, Boston, MA, 1995. p. 204-223. 
91. TOLEDO, J. C. de et al. Qualidade: gestão e métodos. Rio de Janeiro: LTC, p. 48-62, 2013.

92. TORO-VAZQUEZ, J. F. et al. Crystallization kinetics of palm stearin in blends with sesame seed oil. Journal of the American Oil Chemists' Society, v. 77, n. 3, p. 297-310, 2000.

93. TORRES, C. A bíblia do marketing digital: tudo o que você queria saber sobre marketing e publicidade na internet e não tinha a quem perguntar. Novatec Editora, 2018.

94. VAISEY-GENSER, M. MARGARINE| Types and Properties. 2003.

95. VALOR ECONOMICO. 2019. Produtos Saudáveis e práticos estão em alta. Disponível em: https://www.pressreader.com/brazil/valoreconomico/20190319/page/42. Acesso em 30 jun. 2019.

96. VOORHEES, C. M.; BRADY, M. K.; HOROWITZ, D. M. A voice from the silent masses: an exploratory and comparative analysis of noncomplainers. Journal of the academy of marketing science, v. $34, n$. 4, p. 514-527, 2006.

97. WASSEL, P. Industrial margarine and spreads, descriptions solutions. Brabrand - Denmark: Danisco training course, 2005.

98. WIEDERMANN, L. H. Margarine and margarine oil, formulation and control. Journal of the American Oil Chemists' Society, v. 55, n. 11, p. 823-829, 1978

99. ZHANG, H. et al. Storage stability of margarines produced from enzymatically interesterified fats compared to those prepared by conventional methods-Chemical properties. European Journal of Lipid Science and Technology, v. 108, n. 3, p. 227-238, 2006.

100. ZHANG. H.; JACOBSEN, C.; ADLER-NISSEN, J. Storage stability study of margarines produced from enzymatically interesterified fats compared to margarines produced by conventional methods: physical properties. Eur. J. Lipid Sci. Technol. v. 107, p. 530 -539, 2005.

101. ZEVENBERGEN, H.; de BREE A.; ZEELENBERG, M.; LAITINEN, K.; van DUIJN, G.; FLÖTER, E. Foods with a high fat quality are essential for 
healthy diets. Annals of Nutrition and Metabolism, v.54, (suppl 1), p.15-24, jul. 2009 


\title{
Apêndice A: Termo de Consentimento Livre e Esclarecido
}

\section{TERMO DE CONSENTIMENTO UIVRE ESCLARECIDO - TCLE}

Título da pesqulsa: Intuéncia do perfil de fusdo do b́leo na aceltaçdo sensorial de margarina.

Pesqulsadores responsávels: Profa. Dra. Marta Mitsui Kushida e Mestranda Gisele

Fernandes de Oliveira

Contatos: Telefone - 19 35654342; e-mall: martakuahidalivaphr

Número do CAAE

Você está sendo convidado|a) a participar como volunitário(a) da pesquiza de avaliaçäo da influtencia do perfil de fusäo do óleo na aceitaçäo sencorial de margarina.

Este documento, chamodo Temo de Consentimento livre e Eclarecido (TCLE), visa assegurar seve direitoe como paticipante. Por fovor, leia o TCLE com atençöo, e aproveite para esclarecer suas dúvidas com os pesquizadores. Se houver outras dúvidas mesmo depoí de axiná-lo, você poderá esclarecétas. Se preferir, pode levar este Termo para cava e conaultar seva familares ou outras pessoas antes de decidir participar. Após ser esclarecido sobre detalhes da pesquisa, se aceitar fazer parte do estudo, arsine este documento, que the foi enitregue em duas viaz. Uma delas 6 sua e a outra do pesquisador resporsável. Caso näo queira participar da pesquisa ou queira desistir dela em qualquer momento vock näo terá qualquer prejuizo ou será penalizado [a) de forma alguma.

\author{
Informaçoes sobre a pesquisa \\ Objettvos e Justificativa \\ O principal objetivo do teste discriminativo 6 entender, utilzando-se equipe de \\ provadores treinados, se após oscilaçöes de temperatura haverá varioçöes noa \\ atributoa vencoriais de margarinas.
}

O objetivo do teste de aceitoçäo \& avaliar oe atributos sensoriais relacionadoc com o perfil de furbo e que possam impoctar na aceitaçöo do consumidor, seguido de um teste de preferéncia para indicaçäo do consumidor da sua amostra preferida.

\section{Procedimentos} DISCRIMUNATIVO

Nesta pesquisa vocé está sendo convidado a participar da avaloçōo sensoria de margarinas submetidas a diferentes oscilaçöes de temperatura para idenifficar as alteraçöes nas caractevisficas versoriaiz das amostras. As avaloçöes seräo realzadas no Laboratónio Análice Sencorial e será necessário que voce passe por um breve treinamento específico. Você deverá prowar o produto, avalar a apanéncia, sabor amanteigado, gocto salgado e o tempo de derrefimento na boca e responder se existe differença entre 0 controle (sem oscilaçöes de temperatura), e as amostras que ficaram temporariamente nas temperaturas de $10^{\circ} \mathrm{C}=25^{\circ} \mathrm{C}$. Vocô precieará comparecer em apenas uma sessöo para coleta das respostas, avaliará de 7 a 9 amostras diferentes e 0 tempo necesvário para responder é extimado entre 10 e 20 min. Pode haver outros sessäes com o mesmo objefivo de avalioçäo e vocb está convidado a participar das demais sessöes, que aconieceräo em dias que seräo previamente divulgadoc. 


\section{ACETTAÇĀO/ PREFERENCIA}

Nesta perquisa vocé está sendo convidado a participar da avaliaçōo senvoria de margarinas submetidas a diferentes ouciloçöes de temperatura pana identificar a alteraçöes nas caroctenisficas sersoriais das amostras. As avaloçöes seräo realizadas no Laboratório Análize Sensorial e näo será neceszário que você passe por um breve treinamento específco. Voce deverá provar o produto, avaliar a apartincia, vabor, gocto salgado, tempo de derretimento, cremosidade, textura e responder quanto goata ou desgosta do produto escolhendo ao final a amostra preferida. Vock precizará comparecer em apenas uma sessäo para coleta das respostas, avaliará de 2 a 3 amoatras diferentes e o tempo necessário para responder 6 estimado entre 15 e $30 \mathrm{~min}$. Pode haver outras sessöes com o mesmo objefivo de avaloçäo e vocé está convidado a participar das demais sessöes, que aconteceräo em dias que seräo previamente divulgadoc.

\section{Avallaçao de riscos e beneficios}

O concumo de qualquer fipo de alimento, mesmo quando todas as precauçöes quarito à segurança do produto säo tomadas, ainda pode envolver algum réco d̀ soúde, tais como alergias desoonheoidar a um alimento in natura ou aos ingredientes de um almento formulodo. As amoatras que voce vai provar foram fabricados seguindo as normas de boas práticas de fabricaçäo [BPF], as matérias primas e outros ingredientes säo de boa qualidade e procedência conhecida. Além dizo, análses microbiológicas foram realzadas antes doc testes sensoriais para aumentar a confiança de que eles näo causaräo nenhum dano à sua saúde. No entanto, como o produto foi formulado utilizando óleo se voja, ógua, gordura vegetal, soro de leite em pó, leite em pó desnatodo, vitaminas $B(B 6, B 1$ e $B 12\rangle$, vitamina $A$ selenito de sódio [Selârio], estabilizantes mono e digiceídeos de ácidos gravos e lecifina de roja. concervadores: sorbato de potássio, benzoato de sódio, Anfioxidante: TBHQ. BDTA cálcio dissódico e BHT, Acidulante: ácido cítrico, Aromatizante: Aroma: idênfico oo natural, Corantes: urucum, beta caroteno e cúreuma (nöo contém glutén), pode haver problemas para quem apresenta algum fipo de alergia aos ingredientes. Se voce acredita que pode ter alguma reaçōo alíngica ao produto ou veua ingredientes, vock pode decidir nóo participar desta pesquita, ou se quiser peça mais informaçöes quanto aos ingredientes presentes nas amostras.

Se apóa o teste sensorial você senfir qualquer problema que possa estar relacionado ao consumo destes produtos, entre em contato imediatamerte com o[s] pesquisador(es] responsável(eis) pela pesquira, para encaminhamento ao posto de saúde ou horpital mas próximos ou outras providéncias.

O consumo doa produtos no laboratório de Análise Sensorial nāo representa nenhum benefício direto para você, no entanto acreditamos que o desenvolvimento deste estudo pode agregar valor ao conhecimento da Ciéncia de Alimentos em especial à Análise Sentorial.

\section{Outras informaçoes}

Os pesquisadores garantem que sua identidade será mantida em sigilo e nenhuma informaçāo pessoal será dada a outras persoas que näo façam parte da equipe de perquisadores. Na divulgaçäo doa resultadoa desse estudo, seu nome näo verá cifado. Na publicaçäo da pesquisa utiliaremos os resultados da análise do conjunto de dadoe obtidoc. 
Avaliamos que vocb näo ferá despesas para paricipar desta pesquisa nem receberá qualquer pogamento. No entanto, caso ocoma agum dano decomente da sua paricipoçōo na pesquisa, será indenizado.

Em caso de dévidas sobre a pesquisa, yocb poderá entror em contato com a perquisadora, Profa. Dra. Marta Mitrui Kushida, no Departamento de Engenharia de Almentoa, fone 3565.2342 localzado na faculdade de Zootecria e Engenhoria de Almentos, Avenida Duque de Cavias Note, 225, Jardim Eite, Pirassununga-SP - sola 38. Em caso de denúncias ou reclamaçóes sobre sua participoçāo e sobre questöes sticas do estudo, vocé poderá entrar em contato com a secretaria do Comite de Ftica em Pesquisa (CEP) da FZEA no oompus Fernando Costa - Av. Duque de Cavics Norte, 225; CEP 13635-900 Pirassununga - SP; telefione (19) 2565-6759; e-mait seofrealuap.be.

CONSENTIMENTO UIVRE E ESCLARECIDO

Eu,

paricipar do projeto de pesquiza infuencia do pertil de arsinado, concordo em sensorial de margarina.

fui devidamente informado e esclarecido sobre a pesquita, os procedimentos envolvidos, assim como sobre possiveis riscos e berneícioe decomentes de minho participoçöo. Foi-me gavantido que poderei refinar meu consentimento a qualquer momento sem que iszo leve a qualquer penalidade e que podere receber esclarecimentoa sempre que conciderar necessánio. Sera manfido sigio quanto a identificaçōo de mirha pessoa e zelo a minha pivacidade. Declaro estar recebendo uma via original deste documento aszinada pelo pesouizador e por mim, com todas as folhos por nóa rubricadas.

Jundai, de de 2017

Contato telefônico:

e-mail [opcional|:

Data:

(Assinatura do participante ou nome e assinatura do seu RESPOWISÁVEl LEGAL)

Compeomisso do Pesquisador

Asseguro ter cumprido as evigancias da resoluçäo $456 / 2012$ CNG/INS e complementares na elaboraçóo do profocolo e na obtençäo deste Termo de Consentimento livre e Esclarecido. Acseguro, tambúm, ier explicado oc procedimentoc da pesquisa e fornecido uma via deste documento 00 participonte. Informo que o estudo foi aprovado pelo CEP perante o qual o projeto foi apresentado. Comprometome a ufilsar o material e os dadoc obtidos nesta pesquisa evcluvivamente para as finalidades previstas neste documento ou conforme o consentimento dodo pelo parficipante.

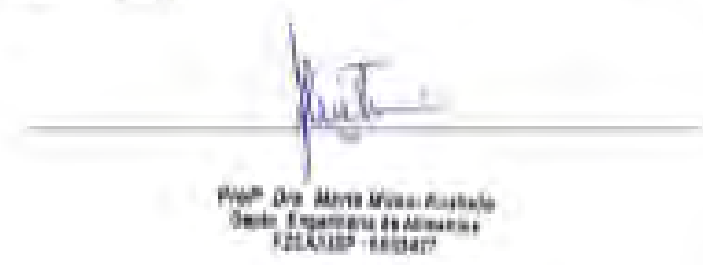
Hitus letion

[Assinatura do pesquisador Data: 


\section{Apêndice B: Comprovante de aprovação do Comitê de Ética em Pesquisa com Humanos (CEPH) da Faculdade de Zootecnia e Engenharia de Alimentos (FZEA/USP)}

\section{मिने स्रिख्या प्जाए \\ USP - FACULDADE DE \\ ZOOTECNIA E ENGENHARIA \\ DE ALIMENTOS DA}

\section{PARECER CONSUBSTANCIADO DO CEP}

\section{DADOS DO PROJETO DE PESQUISA}

Titulo da Pesquisa: Influência do perfil de fusão do óleo na aceitação sensorial de margarina

Pesquisador: Marta Mitsui Kushida

Área Temática:

Versão: 1

CAAE: 74595717.5 .0000 .5422

Instituição Proponente: UNIVERSIDADE DE SAO PAULO

Patrocinador Principal: Financiamento Próprio

DADOS DO PARECER

Número do Parecer: 2.247 .583

\section{Apresentação do Projeto:}

O projeto apresenta, adequadamente, a metodologia que será empregada na análise sensorial e de preferência de uma margarina, preparada pelos pesquisadores e depois submetida a duas variações de temperatura.

\section{Objetivo da Pesquisa:}

Os pesquisadores farão o preparo da margarina, seguindo as boas práticas; posteriormente, submeterão as amostras a 2 variaçöes de temperatura ( 160 ou $25 \circ \mathrm{C}$ por 7 dias) e conduzirão um teste de análise sensorial e um teste de preferência com voluntários, utilizando também uma amostra controle (mantida constantemente $\mathrm{a} 8 \mathrm{oC}$ ). $\mathrm{O}$ intuito é saber se as variações de temperatura poderão alterar as características sensoriais e a preferência dos consumidores.

\section{Avaliação dos Riscos e Benefícios:}

Os riscos inerentes ao preparo da margarina, assim como a possibilidade de alergias aos ingredientes da formulação foram destacados no TCLE.

Aparentemente, os voluntários não terão benefícios, mas contribuirão com a pesquisa.

Comentários e Considerações sobre a Pesquisa:

Protocolo experimental bem elaborado para a os objetivos propostos, ou seja, avaliar se as variaçóes de temperatura podem alterar as propriedades da margarina e sua aceitação pelos voluntários.

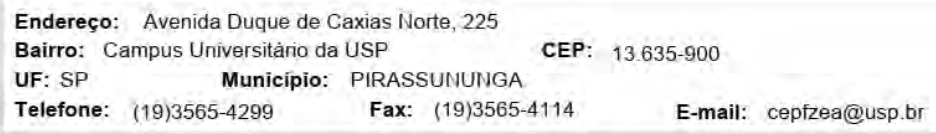




\section{USP - FACULDADE DE ZOOTECNIA E ENGENHARIA DE ALIMENTOS DA

Contınuaçâo do Parecer. 2.247 .583

Considerações sobre os Termos de apresentação obrigatória:

TCLE, formulário de informações básicas e folha de rosto foram corretamente preenchidos, com as informações essenciais sobre o projeto.

Recomendações:

Nada a declarar.

Conclusōes ou Pendências e Lista de Inadequaçōes:

O projeto segue os preceitos da ética, a partir do momento que informa corretamente os procedimentos e os possíveis riscos (mesmo que minimizados pelas boas práticas) aos voluntários.

\section{Considerações Finais a critério do CEP:}

Este CEPH FZEA aprova o desenvolvimento do projeto.

Este parecer foi elaborado baseado nos documentos abaixo relacionados:

\begin{tabular}{|c|c|c|c|c|}
\hline Tipo Documento & Arquivo & Postagem & Autor & Situação \\
\hline $\begin{array}{l}\text { Informações Básicas } \\
\text { do Projeto }\end{array}$ & $\begin{array}{l}\text { PB_INFORMAÇŌES_BÁSICAS_DO_P } \\
\text { ROJETO 976802.pdf }\end{array}$ & $\begin{array}{c}21 / 08 / 2017 \\
10: 00: 52 \\
\end{array}$ & & Aceito \\
\hline Folha de Rosto & folhaDeRostoassinada.pdf & $\begin{array}{c}21 / 08 / 2017 \\
10: 00: 04\end{array}$ & Marta Mitsui Kushida & Aceito \\
\hline $\begin{array}{l}\text { Projeto Detalhado I } \\
\text { Brochura } \\
\text { Investigador }\end{array}$ & PROJETO_GISELE.pdf & $\begin{array}{c}11 / 08 / 2017 \\
10: 51: 59\end{array}$ & Marta Mitsui Kushida & Aceito \\
\hline $\begin{array}{l}\text { TCLE / Termos de } \\
\text { Assentimento / } \\
\text { Justificativa de } \\
\text { Ausência }\end{array}$ & TCLE.pdf & $\begin{array}{c}10 / 08 / 2017 \\
11: 20: 50\end{array}$ & Marta Mitsui Kushida & Aceito \\
\hline
\end{tabular}

Situação do Parecer:

Aprovado

Necessita Apreciação da CONEP:

Não

PIRASSUNUNGA, 30 de Agosto de 2017

\section{Assinado por:}

Daniele dos Santos Martins

(Coordenador)

Endereço: Avenida Duque de Caxias Norte, 225

Bairro: Campus Universitário da USP

UF: SP Municipio: PIRASSUNUNGA

Telefone: (19)3565-4299 Fax: (19)3565-4114

CEP: $\quad 13,635-900$

E-mail: cepfzea@usp.br 


\section{USP - FACULDADE DE ZOOTECNIA E ENGENHARIA DE ALIMENTOS DA

Continuação do Parecer: 2.247.583

Endereço: Avenida Duque de Caxias Norte, 225 